\title{
Constitución y Derecho de daños ${ }^{1}$
}

\author{
Ricardo de Ángel Yágüez \\ Catedrático de Derecho Civil \\ Universidad de Deusto \\ Vocal Permanente en la Sección Civil de la \\ Comisión General de Codificación
}

Recibido: 06.11 .06

Aceptado: 06.11 .06

Resumen: La relación entre Constitución y Derecho privado (o mejor, el impacto que la primera puede tener en el segundo) es una cuestión que siempre ha suscitado el interés de los juristas. Ese interés creció con la promulgación de las Constituciones alemana e italiana de la postguerra. Lo mismo ocurrió en España, a partir de la Constitución de 1978. El presente trabajo tiene por objeto examinar en qué medida puede afectar la Constitución española a una materia tan característica del Derecho privado como es la responsabilidad civil, también conocida (en terminología procedente del common law) como «Derecho de daños».

Palabras clave: Constitución. Derecho privado. Responsabilidad civil. Derecho de daños.

Abstract: The relationship between Constitution and Private Law (or rather, the impact of the first on the second) is a question that have given rise the interest of jurists. This interest grew up with the enactment of the postwar German and Italian Constitutions. The same has happened in Spain, since the Constitution of 1978. With this article I will try to describe the way in which the Spanish Constitution affects such a typical area of Private Law like the one called civil liability or, as it is said in common law terms, «Law on torts».

Key words: Constitution. Private Law. Civil liability. Law on torts.

Sumario: I. Propósito de esta exposición.--II. Algunas consideraciones previas sobre Constitución y Derecho privado.-III. Derecho de daños y Constitución española. A. La noción de «responsabilidad» en la Constitución española. B. La constitucionalidad del deber de reparar el daño. El quantum de la indemnización. C. Constitucionalidad de un régimen de responsabilidad objetiva. Y, también, del principio de inversión de la carga de la prueba en un sistema de responsabilidad por culpa. D. Aspectos constitucionales de la indemnización del llamado «daño moral». E. El problema de los «daños punitivos». Y la indemnización consistente en el beneficio del dañador. F. Responsabilidad civil y presunción de ino-

${ }^{1}$ Este texto es el desarrollo de la ponencia presentada por el autor en el II Congreso de Derecho constitucional: Neoconstitucionalismo y Derecho privado, el debate, celebrado en la Pontificia Universidad Javeriana, de Bogotá, del 13 al 15 de setiembre de 2006. 
cencia. G. La responsabilidad patrimonial de las Administraciones públicas en la Constitución española. La posible responsabilidad patrimonial del Estado legislador. H. Leyes de desarrollo de normas constitucionales atinentes al Derecho de daños. I. El efecto de principios constitucionales en la jurisprudencia sobre responsabilidad civil: a) principio pro damnato y «peregrinaje de jurisdicciones»; b) difuminación de los límites entre responsabilidad contractual y extracontractual; c) significado «constitucional» de algunas inmisiones; d) el «derecho a la salud» y la responsabilidad civil.

\section{Propósito de esta exposición}

1. El objetivo que persigo con la presente aportación es, en síntesis, el de examinar qué reglas, principios o criterios de la Constitución española inciden o pueden incidir en el hoy comúnmente llamado Derecho de daños, esto es, lo que con arreglo a terminología tradicional (de corte europeo, con inspiración del Código civil francés) acostumbramos a denominar responsabilidad civil (o, quizá con más precisión, responsabilidad extracontractual).

El centro de gravedad de mi exposición es, pues, y desde un punto de vista constitucional, el concepto de responsabilidad, en su acepción más limitada de obligación de indemnizar el daño causado injustamente y al margen de cualquier convención entre dañador y víctima.

Quedan excluidas, por tanto, cualesquiera alusiones a responsabilidad política - tan frecuentes en las Constituciones-, así como el aspecto constitucional -muy sugestivo, tanto en el plano sustantivo como en el procesalde las responsabilidades penal y disciplinaria.

En cambio, considero insertas en la responsabilidad civil la denominada, en España, responsabilidad patrimonial de las Administraciones públicas (porque, a mi juicio, no es más que una expresión o modalidad de genuina responsabilidad civil), así como la que, desde una perspectiva «procesal» (mejor, jurisdiccional), se mueve en el ámbito laboral; esto es, la que incumbe al empleador por daños sufridos por el empleado o trabajador.

2. Hay que hacer notar, sin embargo, que la polisemia de la palabra responsabilidad ${ }^{2}$ no deja de jugar alguna mala pasada (y no meramente lingüística) al intérprete.

\footnotetext{
${ }^{2}$ Mi trabajo «Sobre las palabras 'responder', 'responsable' y 'responsabilidad'», en Estudios jurídicos en homenaje al Profesor Luis Díez-Picazo, Civitas, Madrid, 2003, II, pp. 1323-1352. Publicado también en Estudios de Deusto, vol. 50-1, enero-junio 2002, pp. 1144, y en Revista de responsabilidad civil y seguros, Argentina, año V, número 1, enero-febrero de 2003, pp. 1-21.
} 
Es particularmente expresivo el caso del artículo 9.3 de la Constitución española (CE), que reza:

«La Constitución garantiza el principio de legalidad, la jerarquía normativa, la publicidad de las normas, la irretroactividad de las disposiciones sancionadoras no favorables o restrictivas de derechos individuales, la seguridad jurídica, la responsabilidad y la interdicción de la arbitrariedad de los poderes públicos».

¿De quién se predica la responsabilidad? ¿Sólo de los poderes públicos? ¿Sobra una coma y falta una «y»-o un «así como»-? ¿De qué responsabilidad se trata? ¿Es únicamente la política, o también la patrimonial?

La importancia de esta última pregunta se ha puesto de relieve en relación con el problema de la llamada responsabilidad patrimonial del Estado legislador (o por el hecho de las leyes, en expresión directamente traducida de la doctrina francesa). Me remito a lo que luego diré al respecto.

\section{Algunas consideraciones previas sobre Constitución y Derecho pri- vado}

1. Lo que pretendo con este breve capítulo es formular unas reflexiones introductorias sobre las relaciones entre la Constitución (o, si se quiere, el Derecho constitucional) y el Derecho privado. Y, más concretamente, poner de relieve en qué aspectos se ha manifestado esa relación en España, desde la promulgación de la vigente Constitución de 27 de diciembre de 1978.

2. Cuando los constitucionalistas ${ }^{3}$ se refieren (en general, esto es, con independencia de una concreta Constitución) al impacto de la Ley Fundamental en el Derecho privado, coinciden en la apreciación de que ese impacto se manifiesta, básicamente, en tres aspectos:

En primer lugar, en la posibilidad (o no) de atribuir efectos directos a las normas o a los principios constitucionales que se refieren a instituciones de Derecho civil o mercantil.

En segundo término (no es lo mismo que lo anterior, aunque se le parece), los constitucionalistas discutieron en el pasado (hoy casi no lo hacen) sobre si los derechos fundamentales y libertades públicas son o no aplicables -también directamente - a conflictos inter privatos. Es la cuestión que se ha venido a conocer con una expresión en alemán (Drittwirkung der Grundrechte) difícilmente traducible al español, si no es mediante un circunloquio ${ }^{4}$.

\footnotetext{
${ }^{3}$ Por ejemplo, Hesse, Derecho constitucional y Derecho privado, edición española, traducción e introducción de Gutiérrez GutiérRez, Civitas, Madrid, 1995.

${ }^{4} \mathrm{Me}$ ocupé de este punto hace muchos años en «La protección de la personalidad en el Derecho privado», Revista de Derecho notarial, 1974, enero-marzo, pp. 3-138.
} 
En tercer lugar, coinciden en que los dos grandes principios del Derecho privado que pueden verse afectados por el orden constitucional, en el ámbito de lo patrimonial, son la autonomía privada (en definitiva, la libertad) y la responsabilidad.

3. Como «telón de fondo» se encuentran:

En el plano procesal, la existencia de algún sistema (cualquiera de los que conoce el Derecho comparado) de control judicial de la inconstitucionalidad de las leyes, de los reglamentos y de los actos de la Administración.

Desde un punto de vista normativo, la difícil definición o delimitación de lo que se conoce por legislación ordinaria.

Y desde el punto de vista material o sustantivo, está presente la «tensión» (RADBRUCH) entre justicia -lo que hoy solemos denominar justicia material-y seguridad jurídica.

4. Recurriendo de nuevo a HESSE, entiendo que es muy esclarecedora, para describir el curso histórico de las relaciones entre Constitución y Derecho privado, la toma en consideración de las tres grandes etapas que se encuentran en el Derecho alemán, pero que quizá también se hallen en otros ordenamientos.

Es claro que las Constituciones del siglo XIX carecieron de vínculos materiales con el Derecho privado.

Bajo la Constitución del Reich de 1871, las relaciones entre particulares estaban sólo gobernadas por la ley ordinaria. Era ésta la que establecía el marco de libertad del individuo en la convivencia social (una sociedad liberal en un Estado no liberal), así como la responsabilidad del individuo. Se podía entender entonces (hoy resultaría chocante) una interpretación de la Constitución conforme a la ley. De otro lado, en el plano conceptual, el entonces Derecho político se construía con arreglo a los esquemas científicos del Derecho privado: instituciones, conceptos, procedimiento deductivo y construcción de un «sistema».

Bajo la Constitución de Weimar, ésta desplegó un efecto de garantía de las instituciones privadas. Tales garantías sólo tuvieron una función de guía, de directriz, puesto que, concebidos los principios constitucionales como programáticos, no vinculantes, precisaban de una regulación legal. Dicho de otro modo, las normas constitucionales no fundamentaban ningún derecho subjetivo. Con todo, las normas de la Constitución desempeñaron una considerable función preservadora y protectora de los derechos fundamentales en el ámbito privado, en la medida en que quedaba vedado para el legislador ordinario abolir los institutos de Derecho privado constitucionalmente garantizados.

La tercera época, la actual, arranca de la Ley Fundamental de Bonn. Atribuida a la Federación la legislación civil, y declarada la primacía de la Constitución (cuyos derechos fundamentales constituyen reglas jurídicas inme- 
diatamente aplicables), el impacto de la Ley Fundamental en el Derecho privado se manifiesta, sobre todo, en estos aspectos: se reconocen los derechos clásicos (propiedad, herencia, familia, filiación, libertad contractual); se reduce la posibilidad de cualquier limitación legislativa de esos derechos; y se amplía el ámbito de algunos derechos fundamentales, llevándolos al terreno del Derecho privado.

Y, sobre todo, destaca la decisiva función del Tribunal Constitucional Federal. No queriendo ser la Ley Fundamental un orden valorativamente neutral, y debiendo su sistema de valores regir en todos los ámbitos del Derecho (legislación, Administración y jurisprudencia), en todos ellos se debe tener en cuenta la influencia de los derechos fundamentales en la creación, interpretación y aplicación de las normas jurídicas, so pena de declaración de nulidad por parte del Tribunal Constitucional a través del recurso de amparo.

5. El último aspecto de los tres que antes he citado merece alguna atención especial ahora.

- Es evidente el riesgo que corre la «certeza del Derecho» cuando se justifica o «ampara» una solución jurídica en la legalidad constitucional, sin el «filtro» del desarrollo legislativo de esa legalidad.

- Por otro lado, no es menos claro que cuanto mayor sea la generalidad en la descripción del supuesto de hecho de una norma jurídica, también corre mayor peligro la seguridad jurídica.

- Con razón se ha hablado de los peligros que entraña la «huída a la cláusula general», en la traducción legislativa o jurisprudencial de las reglas y de los principios constitucionales.

- Téngase presente que la seguridad jurídica (que puede entenderse, según una de sus perspectivas, como «previsibilidad» de las decisiones judiciales o, en otros términos, un saber a qué atenerse en nuestras relaciones con los demás) goza de notable realce, precisamente, en la Constitución española. El apartado 3 de su artículo 9 declara que la Constitución garantiza, entre otros principios que allí se enumeran, «la seguridad jurídica» ${ }^{5}$.

Y no sólo eso, sino que el párrafo primero del breve preámbulo de nuestra Constitución dice enfáticamente: «La Nación española, deseando establecer la justicia, la libertad y la seguridad y promover el bien de cuantos la integran, en uso de su soberanía, programa su voluntad de...». Aunque la palabra seguridad, en este texto, pueda tener un alcance mayor que el de seguridad jurídica, no parece dudoso que ésta también va incluida.

\footnotetext{
${ }^{5}$ Ese apartado 3 reza: «La Constitución garantiza el principio de legalidad, la jerarquía normativa, la publicidad de las normas, la irretroactividad de las disposiciones sancionadoras no favorables o restrictivas de derecho individuales, la seguridad jurídica, la responsabilidad y la interdicción de la arbitrariedad de los poderes públicos».
} 
6. Además, y otra vez es forzoso acudir a la brillante síntesis de Hesse, es notable el riesgo de que, por virtud de la primacía de la Constitución, y de la doctrina constitucional, pueda perderse, o al menos verse seriamente afectada, la identidad del Derecho privado.

Un ejemplo: una figura privada tan indudable como es la renunciabilidad de los derechos, podría quedar en entredicho ante el dogma de que los derechos fundamentales no pueden ser nunca objeto de renuncia.

Y no menos desdeñable es, en este mismo aspecto, el peligro (en rigor, una realidad) de que los jueces tiendan a razonar (incluso no siendo necesario) por la senda de los derechos fundamentales, siendo así que muchas de sus «soluciones» pueden estar plenamente fundadas (sólo) en conceptos o principios clásicos de la dogmática del Derecho privado.

Lo cual, por cierto, podría llevar a un cierto paralelismo con las ironías que IHERING hizo al final de su vida sobre el abuso de la noción de derecho subjetivo (el derecho a bailar, a rascarse o a sudar).

No creo que sea exagerado hablar del «riesgo» de inflación de derechos fundamentales, si los Tribunales, aunque con muy buena intención, intentan encontrar por doquier tales derechos. Pienso en el «derecho a que a uno le dejen solo» (the right to be let alone, de la jurisprudencia norteamericana ${ }^{6}$ ), o en el «derecho a no haber nacido» (the right not to be born, puesto en circulación como consecuencia de las llamadas acciones de wrongful birth y de wrongful life, con origen también en Estados Unidos, pero de las que ya tenemos casos en España ${ }^{7}$ ), o en el derecho humano a no tener que soportar ruidos superiores a lo normal.

7. El impacto de la Constitución de 1978 en el Derecho privado español ha sido notabilísimo.

El carácter de norma jurídica reconocido a nuestra Constitución ${ }^{8}$, esto es, superada la idea de una Constitución programática ${ }^{9}$, entraña la eficacia directa de los mandatos constitucionales, fácilmente deducible de los artículos 9.1 y 53.1 y 2 , de la propia Ley Fundamental ${ }^{10}$.Y que se encarga de recor-

\footnotetext{
${ }^{6}$ Me referí a él en mi artículo «La protección de la personalidad...», citado.

${ }^{7}$ Me remito a varios trabajos que he publicado sobre las cinco sentencias que el Tribunal Supremo español ha dictado sobre tan sugestivos y delicados problemas.

${ }^{8}$ Sobre todo, a partir del trabajo de GARCÍA DE ENTERRÍA, «La Constitución como norma jurídica», en Anuario de Derecho civil, 1979, pp. 219 ss.

${ }^{9}$ Notable contraste con lo que DE CASTRO escribió en su trabajo «El Derecho civil y la Constitución», a la luz de la Constitución republicana de 1931, en Revista de Derecho privado, 1935, 257, pp. 3-ss.

${ }^{10}$ Artículo 9: "1. Los ciudadanos y los poderes públicos están sujetos a la Constitución y al resto del ordenamiento jurídico. 2. Corresponde a los poderes públicos promover las condiciones para que la libertad y la igualdad del individuo y de los grupos en que se integran sean reales y efectivas; remover los obstáculos que impidan o dificulten su plenitud y facilitar la participación de todos los ciudadanos en la vida política, económica, cultural y
} 
dar la Ley Orgánica del Poder Judicial, en sus artículos 5.1 y 7, apartados 1 y 2 , sobre todo ${ }^{11}$.

Todo ello, desde luego, con la cobertura de las «cuestiones de constitucionalidad» y del recurso de amparo, de los artículos 35 y 41 de la Ley Orgánica del Tribunal Constitucional, de 3 de octubre de $1979^{12}$.

social. 3. La Constitución garantiza el principio de legalidad, la jerarquía normativa, la publicidad de las normas, la irretroactividad de las disposiciones sancionadoras no favorables o restrictivas de derechos individuales, la seguridad jurídica, la responsabilidad y la interdicción de la arbitrariedad de los poderes públicos». Y artículo 53: «1. Los derechos y libertades reconocidos en el Capítulo segundo del presente Título vinculan a todos los poderes públicos. Sólo por ley, que en todo caso deberá respetar su contenido esencial, podrá regularse el ejercicio de tales derechos y libertades, que se tutelarán de acuerdo con lo previsto en el artículo 161.1 a). 2. Cualquier ciudadano podrá recabar la tutela de las libertades y derechos reconocidos en el artículo 14 y la Sección primera del Capítulo $2 .^{\circ}$ ante los Tribunales ordinarios por un procedimiento basado en los principios de preferencia y sumariedad y, en su caso, a través del recurso de amparo ante el Tribunal Constitucional. Este último recurso será aplicable a la objeción de conciencia reconocida en el artículo $30 »$.

${ }^{11}$ Artículo 5.1: «1. La Constitución es la norma suprema del ordenamiento jurídico, y vincula a todos los Jueces y Tribunales, quienes interpretarán y aplicarán las leyes y los reglamentos según los preceptos y principios constitucionales, conforme a la interpretación de los mismos que resulte de las resoluciones dictadas por el Tribunal Constitucional en todo tipo de procesos». Y artículo 7, apartados 1 y 2: «1. Los derechos y libertades reconocidos en el Capítulo Segundo del Título I de la Constitución vinculan, en su integridad, a todos los Jueces y Tribunales y están garantizados bajo la tutela efectiva de los mismos. 2. En especial, los derechos enunciados en el artículo 53.2 de la Constitución se reconocerán, en todo caso, de conformidad con su contenido constitucionalmente declarado, sin que las resoluciones judiciales puedan restringir, menoscabar o inaplicar dicho contenido».

${ }^{12}$ Artículo 35: «1. Cuando un Juez o Tribunal, de oficio o a instancia de parte, considere que una norma con rango de ley aplicable al caso y de cuya validez dependa el fallo pueda ser contraria a la Constitución, planteará la cuestión al Tribunal Constitucional con sujeción a lo dispuesto en esta Ley. 2. El órgano judicial sólo podrá plantear la cuestión una vez concluso el procedimiento y dentro del plazo para dictar sentencia, debiendo concretar la Ley o norma con fuerza de ley cuya constitucionalidad se cuestiona, el precepto constitucional que se supone infringido y especificar y justificar en qué medida la decisión del proceso depende de la validez de la norma en cuestión. Antes de adoptar mediante auto su decisión definitiva, el órgano judicial oirá a las partes y al Ministerio Fiscal para que en el plazo común e improrrogable de diez días puedan alegar lo que deseen sobre la pertinencia de plantear la cuestión de inconstitucionalidad, resolviendo el Juez seguidamente y sin más trámite en el plazo de tres días. Dicho auto no será susceptible de recurso de ninguna clase. No obstante, la cuestión de inconstitucionalidad podrá ser intentada de nuevo en las sucesivas instancias o grados en tanto no se llegue a sentencia firme». Y artículo 41: «1. Los derechos y libertades reconocidos en los artículos 14 a 29 de la Constitución serán susceptibles de amparo constitucional, en los casos y formas que esta Ley establece, sin perjuicio de su tutela general encomendada a los Tribunales de Justicia. Igual protección será aplicable a la objeción de conciencia reconocida en el artículo 30 de la Constitución. 2. El recurso de amparo constitucional protege a todos los ciudadanos, en los términos que la presente Ley establece, frente a las violaciones de los derechos y libertades a que se refiere el apartado anterior, originadas por disposiciones, actos jurídicos o simple vía de hecho de 
8. Como no podía menos de ser, la promulgación de la Constitución determinó la necesidad de llevar a cabo considerables reformas en algunos sectores del Derecho privado, sobre todo en el Derecho de la persona, en el de familia y en el de sucesiones. De otro lado, justificó la promulgación de una buena serie de disposiciones legales de conversión a legalidad ordinaria de normas o principios de la Carta Magna. Al significado de ambos fenómenos, en el Derecho de la responsabilidad civil, me refiero en el capítulo III de este trabajo.

9. Por otro lado, la Constitución es fuente inspiradora de principios generales del Derecho. Téngase presente que éstos son fuente del ordenamiento jurídico español, según el artículo 1.1 del Código civil. Y que, como dice el apartado 4 del mismo precepto, «los principios generales de derecho se aplicarán en defecto de ley o costumbre, sin perjuicio de su carácter informador del ordenamiento jurídico».

El Profesor DE CASTRO, en su gran Derecho civil de España ${ }^{13}$, al abordar la ardua tarea de determinar qué son y cuáles son los principios generales del Derecho, incluyó entre ellos, junto a los de Derecho natural y a los tradicionales, los que él denominó políticos. Parece fuera de toda duda que la Ley Fundamental es fuente inspiradora de principios generales, que como tales podrían invocarse en su calidad de norma jurídica, sin perjuicio de que además tengan un efecto inspirador de la legislación ${ }^{14}$.

10. Es ostensible el «entusiasmo» con el que los Tribunales españoles, de todo orden y grado, acogieron enseguida en sus resoluciones normas y principios de la Carta Magna de nuestro país.

Esa presencia de la Constitución en las sentencias fue y sigue siendo particularmente patente en los ámbitos jurisdiccionales penal, laboral y contencioso-administrativo, pero grande también en el orden civil. En el siguiente capítulo III me ocuparé, precisamente, del terreno del Derecho de daños.

11. Por lo que se refiere a la doctrina, formidable ha sido y sigue siendo el impacto de la Constitución con la que se recuperaba el régimen democrático. La obra Constitución Española (25 años de bibliografía) ${ }^{15}$, con sus

los poderes públicos del Estado, las Comunidades Autónomas y demás entes públicos de carácter territorial, corporativo o institucional, así como de sus funcionarios o agentes. 3. En el amparo constitucional no pueden hacerse valer otras pretensiones que las dirigidas a restablecer o preservar los derechos o libertades por razón de los cuales se formuló el recurso».

${ }^{13}$ Reedición facsímil, Civitas, 1984, I, pp. 405 ss.

${ }^{14}$ Sobre este extremo, ARCE y FlóREZ-VALdÉs, Los principios generales del Derecho y su formulación constitucional, Civitas, Madrid, 1990.

${ }^{15}$ Centro de Estudios Políticos y Constitucionales, Madrid, 2003. 
1800 páginas de referencias, da cumplida cuenta de la (en su día inimaginable) fuente de inspiración que la Ley Fundamental ha sido para los juristas españoles.

En el propio compendio bibliográfico que acabo de citar se encuentran, para no entrar en más detalles, abundantísimos títulos que versan, precisamente, sobre Constitución y Derecho privado; esto es, el objeto del presente Congreso.

Basta leer el índice de cualquier manual o tratado de Derecho civil o mercantil, o el de muchísimas monografías, o el de las revistas de Derecho privado, para advertir que la referencia a la Constitución está presente. Incluso, a veces, en los extremos y a los efectos más insospechados.

Y quizá no esté de más señalar que desde hace ya veinte años se publica una revista anual que lleva por nombre el de Derecho privado y Constitución ${ }^{16}$.

12. Por fin, es posible que la denominación pueda parecer un tanto exagerada, según el sentido en que se la entienda, pero no cabe ignorar que en algún sector de la doctrina se propone la existencia de un genuino Derecho civil constitucional $^{17}$.

\section{Derecho de daños y Constitución española}

Me ocupo ahora de lo que es el objeto propiamente dicho de esta aportación, es decir, de algunos extremos que inspiran reflexiones sobre la presencia de la responsabilidad civil en la Constitución española y sobre el impacto que la Ley Fundamental ha producido, en esa materia, en la legislación y en la jurisprudencia de nuestro país.

\section{A. La noción de 'responsabilidad' en la Constitución española}

Inexorablemente ligados los conceptos de daño y responsabilidad, creo que no es inoportuno examinar cuándo y cómo aparece esa segunda noción (la de responsabilidad) en nuestra Constitución.

\footnotetext{
${ }^{16}$ Editada por Centro de Estudios Políticos y Constitucionales, Madrid.

${ }^{17}$ Por ejemplo, PerLingIERI, que, con independencia de sus obras en italiano y referidas a la Constitución de su país, ha escrito «Por un Derecho civil constitucional español», en Anuario de Derecho civil, 1983, enero-marzo, pp. 1-ss. También, ARCE y FlóREZ-VALDÉs, El Derecho civil constitucional, Civitas, 1986. Con las referencias doctrinales que en ambos trabajos se hacen.
} 
En primer lugar, se observa que el principio de responsabilidad del individuo no está presente en nuestra Ley Fundamental ${ }^{18}$.

En segundo término, es patente la escasa presencia del concepto de responsabilidad, bien sea en su forma verbal (responder), bien en sus derivados, bien en conceptos conexos (por ejemplo, indemnizar o sinónimos). Si no cuento mal, son dieciséis las ocasiones en las que la idea de responsabilidad se encuentra en el texto de la Constitución.

En algunos casos, la palabra «responsabilidad» se utiliza en el sentido de «responsabilidad política», exclusivamente: artículos 56, 64, 113, 115 y 152.

Es discutible (y discutido) que se trate sólo de responsabilidad política la referencia que el artículo 9.3 hace a la responsabilidad de los poderes públicos. Lo he apuntado antes y volveré sobre ello.

Constituyen ejemplos de «responsabilidad», en el sentido político y a la vez jurídico de la palabra, los artículos 98.2 y 116.6, aunque en este último caso es dudoso que la eventual significación jurídica sea precisamente la de responsabilidad patrimonial.

En dos ocasiones (artículos 55.2 y 102), la responsabilidad a la que se refiere el texto es la de carácter penal.

Y por lo que respecta a la responsabilidad civil (en el más amplio sentido jurídico de deber de indemnizar), el término «responsabilidad», o afines, se encuentra en los siguientes pocos lugares:

En el artículo 33, relativo a la expropiación forzosa, aunque en este caso la palabra «indemnización» no tiene su raíz en la noción jurídica de responsabilidad (obligación derivada de acto ilícito dañoso), sino que es fruto de una obligación derivada de la ley.

El apartado 2 del artículo 106 constituye un precepto capital, aunque hacía ya tiempo afincado en nuestro ordenamiento jurídico, puesto que formula el principio de responsabilidad patrimonial de las Administración públicas. Luego volveré sobre ello.

El artículo 117.1 versa sobre la responsabilidad de jueces y magistrados.

El 121, sobre la responsabilidad de la Administración de Justicia, entre otros motivos por error judicial.

El 136 describe como una de las funciones del Tribunal de Cuentas la de notificar a las Cortes Generales las «responsabilidades» que hubiere detectado.

Por fin, el artículo 149.1.18. ${ }^{\circ}$ reserva al Estado la competencia legislativa en materia de sistemas de responsabilidad de todas las Administraciones públicas.

${ }^{18}$ Fenómeno, por otra parte, patente en otras Constituciones actuales. No quiero incurrir en la ironía de decir que quizá sea consecuencia de lo poco dadas que son las sociedades de nuestros días a términos «ingratos» como son obligaciones y responsabilidades. 
Con notable osadía, me aventuro a hacer parecido análisis sobre la Constitución de Colombia.

(Como observaciones previas, me atrevo a destacar, primero, lo que $a$ sensu contrario podría deducirse del artículo 85, cuando proclama que son «de aplicación inmediata» los artículos allí citados, es decir, los 11 a 37 -excepto 22, 25, 32, 35 y 36- y 40. En segundo término, encuentro en el artículo 83 un precepto que, amén de ser original, puede constituir una «fuente» de responsabilidades atípicas ${ }^{19}$ ).

$\mathrm{El}$ «fenómeno» de la responsabilidad (esto es, del ser responsable) se encuentra, si no me equivoco, en cuarenta y dos ocasiones.

En algunos casos, responsable se utiliza como sustantivo, esto es, en el sentido de persona a quien se confía una gestión o un cargo. Se halla en los artículos 130, 268.1 y 268.2.

Singular, aunque muy oportuna, es la mención a una responsabilidad moral en el artículo 67, al aludirse a la que el Estado, la sociedad y la familia tienen en relación con la educación.

También es notable, aunque fuera de nuestro marco, el uso de responsable y responsablemente para referirse a la paternidad (o, si se quiere, a la procreación, para que no se me tache de sexista), en el artículo 42 -en tres ocasiones-.

Creo que sólo se refieren a responsabilidad política los artículos 115, 133 у 196.

La responsabilidad de la que habla el artículo 175 es la de carácter penal.

La idea de responsabilidad en sentido jurídico, pero de carácter general (esto es, no sólo necesariamente la de significado patrimonial), se encuentra en los siguientes artículos: 28, 78, párrafo segundo ${ }^{20}, 95^{21}, 198$, $210,211,214.5,215,251.5,268.8$ y el no menos notable 333, párrafo segundo, cuando dispone que «la libre competencia económica es un derecho de todos que supone responsabilidades».

A responsabilidad civil en su acepción más estricta se refiere el artículo 201.2. Pero, sobre todo, es de destacar el artículo 88, párrafo tercero, que remite a la ley la definición de los casos de responsabilidad civil objetiva por el daño inferido a los derechos e intereses colectivos.

${ }^{19} \mathrm{El}$ artículo dice que «las actuaciones de los particulares y de las autoridades públicas deberán ceñirse a los postulados de la buena fe, la cual se presumirá en todas las gestiones que aquéllos adelanten ante éstas».

${ }^{20}$ No puedo dejar de reproducir su texto: «Serán responsables de acuerdo con la ley, quienes en la producción y en la comercialización de bienes y servicios, atenten contra la salud, la seguridad y el adecuado aprovisionamiento a consumidores y usuarios». Y ello, dentro del acertado Capítulo III del Título II, cuyo objeto es «de los derechos colectivos y del ambiente».

${ }^{21}$ También merece ser destacado, porque no es un precepto de estilo: «El ejercicio de los derechos y libertades reconocidos en esta Constitución implica responsabilidades». 
La responsabilidad de la Administración (o, en general, de los poderes públicos) se encuentra en los siguientes artículos:

El 58, indemnización en caso de expropiación, que en realidad no es un caso de responsabilidad; 59, expropiación en caso de guerra y sin indemnización previa; 90 (precepto capital, equivalente al 106.2 de la Constitución española, con la particularidad de que la norma se refiere sólo al Estado ${ }^{22}$ ); 136.4; 150.17; 266; 268.5; 336, párrafo segundo ${ }^{23} ; 365$, párrafo segundo ${ }^{24} ; 367$, párrafo primero ${ }^{25}$; y artículo transitorio 43.

\section{B. La constitucionalidad del deber de reparar el daño. El 'quantum' de la indemnización}

Como hemos visto antes, en nuestra Constitución (CE) no se encuentra formulada expresamente la regla de responsabilidad civil, con la salvedad, también apuntada y a la que enseguida me referiré, de la responsabilidad patrimonial de las Administraciones públicas.

Quiere decir que no existe una norma constitucional que recoja el principio neminem laedere (principio que como tal, es decir, como mandato de «no dañar a nadie», tampoco se suele encontrar en los Códigos civiles), ni la regla del deber de reparar el daño causado injustamente. Es un silencio quizá razonable, en tanto que tampoco es frecuente que una Ley Fundamental aluda, por ejemplo, a la obligatoriedad de los contratos o al principio de libertad de pactos. Del mismo modo que tampoco se suelen hallar referencias, en otro orden de cosas, a la facultad de enajenar, a la sucesión intestada, a la prescripción o a la nulidad de los actos contrarios a la ley. Y fuera del ámbito del Derecho civil, no es fácil encontrar menciones constitucionales, también como ejemplo, al capital principio jurídico de que la comisión del delito lleva aparejada la aplicación de una pena.

El silencio de la Constitución sobre la responsabilidad se solventa, sin embargo, con la idea de que las reglas y los principios rectores del Derecho privado se entienden incluidos en el valor «justicia»-regla moral, principio de cualquier orden jurídico- que, en el caso español, constituye, junto con la libertad, la igualdad y el pluralismo político, uno de los «valores superiores del ordenamiento jurídico» (artículo 1.1 CE y primer párrafo de su preámbulo).

${ }^{22}$ El párrafo segundo de este artículo 90 constituye también una regla de responsabilidad; la del agente autor material del daño. Esta norma tiene relación con la de los dos párrafos del artículo 91 y con la del 124, sobre responsabilidad de los servidores públicos.

${ }^{23}$ Esta regla es, a mi juicio, un ejemplo de responsabilidad patrimonial del Estado legislador. No ha lugar a la controversia, a diferencia de lo que ocurre en España, porque la propia Constitución lo dispone, aunque sólo para el limitado supuesto del precepto.

${ }^{24}$ Precepto que suscita un comentario similar al del precedente.

${ }^{25}$ ¿Es una norma redundante respecto a la del artículo 90? Quizá no, por cuanto se dispone el sometimiento a una ley específica en materia de prestación de los servicios públicos domiciliarios. 
A continuación veremos cómo el Tribunal Constitucional español (TC) tuvo oportunidad de manifestarse sobre el carácter «constitucional» de la regla que impone el deber de indemnizar el daño, con ocasión y motivo de un caso que tuvo durante muchos años en vilo al mundo jurídico de nuestro país.

1. El caso del que hablo fue el derivado de las cuestiones de inconstitucionalidad que varios órganos judiciales españoles plantearon como consecuencia del llamado «sistema para la valoración de los daños y perjuicios causados a las personas en accidentes de circulación», introducido en nuestro ordenamiento mediante una disposición adicional de una Ley de 8 de noviembre de $1995^{26}$.

Ese «sistema» consiste en un Anexo de la Ley sobre responsabilidad civil y seguro en la circulación de vehículos a motor, hoy constituida por el texto refundido aprobado por Real Decreto Legislativo de 29 de octubre de 2004. Era, y es, una notable novedad legal, por cuya virtud todos los daños «personales» sufridos por la víctima de un accidente de circulación quedan sometidos, a efectos de su cuantificación, a un sistema de «tablas» (para entendernos, «baremos»), suficientes para determinar el montante de la indemnización. El efecto fundamental del sistema, por lo tanto, es el de poner fin casi totalmente (es decir, con estrechos márgenes de discrecionalidad) al principio tradicional de libre determinación por el juez de la cuantía de la indemnización, en el tipo de daños al que la Ley se refiere, según lo probado en cada concreto juicio.

Varios órganos judiciales españoles, como decía, plantearon ante el Tribunal Constitucional sendas «cuestiones de inconstitucionalidad», suscitando dudas acerca del ajuste o no a la Constitución del nuevo -en buena medida revolucionario- sistema legal. En concreto, las dudas de constitucionalidad versaban sobre la posible incidencia en los siguientes preceptos de la Carta Magna:

Artículo 15, según el cual «todos tienen derecho a la vida y a la integridad física y moral».

Artículo 14, que proclama que «los españoles son iguales ante la ley».

Artículo 9.3, por cuya virtud la Constitución garantiza, entre otros, «la interdicción de la arbitrariedad de los poderes públicos»; norma que los órganos proponentes ponían en relación con «la justicia», uno de los valores superiores del ordenamiento jurídico según el artículo 1.1 CE.

${ }^{26}$ Este extremo se desarrolla ampliamente por REGLERO CAMPOS en Tratado de responsabilidad civil, varios autores, obra coordinada por el mismo REGLERO CAMPOS, 2. edición, Aranzadi, Cizur Menor, 2003, pp. 90-ss., bajo el epígrafe «Responsabilidad civil y Constitución». Existe una 3. a edición. 
Artículo 117.3, en cuanto declara que «el ejercicio de la potestad jurisdiccional en todo tipo de procesos, juzgando y haciendo ejecutar lo juzgado, corresponde exclusivamente a los Juzgados y Tribunales determinados por las leyes».

Se alegaba también el derecho del individuo a la tutela efectiva de los jueces y tribunales en el ejercicio de sus derechos e intereses legítimos, según el artículo 24.1 de la Ley Fundamental.

Debe señalarse que, como queda dicho, el sistema legal versa sólo sobre los daños «a las personas», puesto que en materia de «daños en los bienes» se deja subsistente el tradicional principio de libre y discrecional valoración por parte del juez, y sobre la base de la regla de la reparación íntegra.

No es ése, sin embargo, el caso de los llamados «perjuicios económicos» derivados de muerte o de lesiones, y consistentes en la pérdida de ingresos (o ingresos dejados de percibir) como consecuencia del fallecimiento o de la lesión, puesto que tales perjuicios quedan también sometidos al sistema de «tablas»; a cuyo fin, las II, IV y V «estandarizan» esos daños en «grupos», en función de cuatro «estratos» según los ingresos netos anuales de la víctima, desde los más exiguos hasta los más elevados.

Ha de añadirse también que los «daños morales» inherentes a la muerte, a la lesión permanente o a la incapacidad temporal se encuentran expresamente incluidos en las cantidades «tasadas» que en las propias tablas se establecen para cada caso. Por poner un ejemplo, tantas pesetas, hoy euros, para un fallecido de 40 años, casado y con dos hijos; o para la víctima de la amputación de una pierna, de 22 años de edad.

A todo esto, hay que decir que la fórmula legal había suscitado ardientes controversias en el mundo jurídico español. Fueron muchos (los más) los autores españoles que se manifestaron detractores del sistema, algunos con particular vehemencia. La propia Sala de lo civil (Primera) del Tribunal Supremo llegó a manifestarse, siquiera como obiter dictum, en contra de lo que en la Ley se manifestaba -al menos según la letra- como incuestionable; esto es, que el sistema vincula a los jueces, tanto en juicios civiles como penales.

Acumuladas en un mismo procedimiento diez cuestiones de inconstitucionalidad, el TC las resolvió mediante su sentencia 181/2000, de 29 de junio.

Tan singular asunto permitió al TC formular, como fundamento de su fallo, consideraciones de orden constitucional de notable interés en materia de responsabilidad civil; y, en concreto, sobre facultades y límites del legislador en punto a la reparación del daño.

La sentencia del Pleno del Constitucional, en la que hubo cuatro votos particulares o disidentes, estimó parcialmente las «cuestiones» planteadas, declarando inconstitucional el sistema en cuanto a los llamados «perjuicios económicos» (el citado capítulo de «pérdida de ingresos») derivados de la tabla V; esto es, la que contempla los casos de incapacidad temporal, si bien el fallo es fácilmente extensible a los mismos «perjuicios económicos» en 
los supuestos de muerte o de lesión permanente, es decir, los de las tablas II y IV. Declaró el TC que el régimen legal «tasado» de la indemnización de dichos perjuicios no vincula a los jueces en aquellos supuestos en que el daño a la persona tenga su causa exclusiva en una «culpa relevante» del agente causante del hecho lesivo.

Expuesto el marco de la sentencia, interesa ahora detenerse en algunos pasajes que, por así decirlo, tienen que ver con la doctrina general de la responsabilidad civil.

2. En primer lugar, procede advertir que al comienzo de sus fundamentos jurídicos, después de haber sentado los presupuestos de la cuestión, la resolución contiene dos párrafos en los que justifica las dudas de constitucionalidad planteadas y parece autocalificarse como intérprete único de la Constitución. Dicen esos párrafos:

«Los órganos judiciales proponentes estiman que la referida regulación legal les vincula jurídicamente en todos sus extremos, impidiéndoles atender a las singularidades del caso concreto y satisfacer, en su caso, pretensiones resarcitorias derivadas de daños procesalmente acreditados y no contemplados en el baremo, o que superan los límites indemnizatorios legalmente establecidos en aquél.

Pues bien, esta inicial premisa interpretativa ha de ser compartida como acertada. No cabe albergar duda alguna acerca de que la obligación constitucionalmente impuesta a los Jueces y Tribunales de aplicar las leyes postconstitucionales vigentes, no puede ser desatendida por el hecho de que se haya acudido a una pretendida interpretación de sus contenidos conforme a la Constitución».

De otro lado, también al comienzo de sus razonamientos, el TC se hace eco del fenómeno conocido como «transformaciones» de la responsabilidad civil, en cuyo marco sitúa las innegables originalidad y novedad -al margen de cualquier otra apreciación- características del sistema objeto de enjuiciamiento. Dice al respecto:

«En suma, la decisión del legislador de establecer, con carácter vinculante, un sistema legal de predeterminación y cuantificación tasada de las indemnizaciones por los daños corporales producidos como consecuencia de la circulación de vehículos a motor, ha de situarse en un momento de renovación del instituto de la responsabilidad civil, especialmente significativo en su proyección al sector del automóvil que, por su alta siniestralidad y por la garantía en la reparación del daño que supone el aseguramiento obligatorio, entre otros factores, ofrece una serie de particularidades necesitadas de soluciones jurídicas diferenciadas».

También como pronunciamiento previo, el TC sienta un principio constitucional en materia de reparación del daño personal. Manifiesta: 
«Además, en todos estos casos, el legislador deberá reparar el daño personal que se hubiese ocasionado acogiendo aquel remedio sustitutivo que deje a la víctima en una situación lo más próxima posible a aquélla de la que disfrutaría si el hecho lesivo no se hubiese llegado a producir, lo que convierte al tradicional principio civil de la reparación integral en contenido necesario de la tutela civil de los daños personales. Puesto que no es posible la reparación "in natura" de la vida ni de la integridad física y moral, de entre los distintos remedios posibles para reparar civilmente los daños corporales el legislador deberá optar por aquel que más se aproxime a la consecución, en cada caso, de la total indemnidad del daño personal sufrido por la víctima».

3. Refiriéndose a la posible conculcación del artículo 15 de la Constitución, derecho a la vida y a la integridad física y moral, el Tribunal dice a modo de principio:

«La protección constitucional de la vida y de la integridad personal (física y moral) no se reduce al estricto reconocimiento de los derechos subjetivos necesarios para reaccionar jurídicamente frente a las agresiones a ellos inferidas, sino que, además, contiene un mandato de protección suficiente de aquellos bienes de la personalidad, dirigido al legislador y que debe presidir e informar toda su actuación, incluido el régimen legal del resarcimiento por los daños que a los mismos se hubiesen ocasionado».

Pero el Tribunal formula a continuación una puntualización determinante de su conclusión de que no cabe oponer ningún reparo a la constitucionalidad de las normas legales cuestionadas, desde el punto de vista del artículo 15 de la Ley Fundamental. Dice la Sala:

«No obstante, y a diferencia de lo argumentado en los Autos de planteamiento, ese mandato constitucional de protección suficiente de la vida y de la integridad personal no significa que el principio de total reparación del dañado encuentre asiento en el art. 15 de la Constitución. Es cierto que el instituto de la responsabilidad civil requiere, de modo inexcusable, que se fije para aquellos bienes de la personalidad un valor patrimonial ( $\mathrm{pecu}$ nia doloris), puesto que la reparación civil del daño descansa en el derecho del dañado a percibir una indemnización. Cierto también, que en el ejercicio de la pretensión resarcitoria de tales bienes aparecen integrados o aunados los conceptos de reparación del estricto daño personal y de restablecimiento de los daños y perjuicios de índole patrimonial que traen causa de la lesión a los bienes de la personalidad (vida e integridad física y moral). Sin embargo, en el plano constitucional no es posible confundir la reparación de los daños a la vida y a la integridad personal (art. $15 \mathrm{CE}$ ), con la restauración del equilibrio patrimonial perdido como consecuencia de la muerte o de las lesiones personales padecidas, pues el mandato de especial protección que el art. $15 \mathrm{CE}$ impone al legislador se refiere estric- 
ta y exclusivamente a los mencionados bienes de la personalidad (vida, integridad física y moral), sin que pueda impropiamente extenderse a una realidad jurídica distinta, cual es la del régimen legal de los eventuales perjuicios patrimoniales que pudieran derivarse del daño producido en aquellos bienes».

De ahí que el TC concluya sobre este primer extremo:

«Se comprende así por qué el mandato constitucional dirigido al legislador, en orden a que adopte los remedios normativos necesarios para ofrecer una satisfactoria protección jurídica de la vida y la integridad personal (art. $15 \mathrm{CE}$ ), es difícilmente conciliable con cualquier intento de valoración y cuantificación de los daños producidos a aquellos bienes jurídicos, y que pueda variar significativamente en función de las circunstancias particulares de su titular. Si en el ámbito de la responsabilidad civil, la vida y la integridad (física y moral) han de ser objeto de cuantificación dineraria o patrimonial, el más elemental respeto a la dignidad humana (art. 10.1 CE) obliga a que aquélla sea la misma para todos. Por esta razón, el art. $15 \mathrm{CE}$ sólo condiciona al legislador de la responsabilidad civil en dos extremos: en primer lugar, en el sentido de exigirle que, en esa inevitable tarea de traducción de la vida y de la integridad personal a términos económicos, establezca unas pautas indemnizatorias suficientes en el sentido de respetuosas con la dignidad que es inherente al ser humano (art. 10.1 CE); y en segundo término, que mediante dichas indemnizaciones se atienda a la integridad -según la expresión literal del art. 15 CE- de todo su ser, sin disponer exclusiones injustificadas.

La anterior clarificación y determinación del canon de constitucionalidad permite concluir que el sistema de baremación legal cuestionado no es contrario al art. 15 de la Constitución. En efecto, el baremo atiende no sólo al supuesto de muerte, sino también a las lesiones causadas en la integridad física y moral de las personas, disponiendo (apartado 1, punto 5 del Anexo), a los efectos de la determinación de la correspondiente responsabilidad civil, unas indemnizaciones básicas por muerte (tabla I) y por lesiones permanentes, incluidos los daños morales (tabla III), cuyas cuantías no pueden estimarse insuficientes desde la apuntada perspectiva constitucional; sin que, por otra parte, en ninguna de las cuestiones planteadas se susciten problemas relativos a la irreparabilidad civil de determinadas lesiones físicas o padecimientos morales que, originados en ese concreto contexto de la circulación de vehículos a motor, hayan sido expresamente excluidos por el legislador del sistema de tablas contenido en el Anexo de la Ley 30/1995».

4. Aborda luego el TC la duda de constitucionalidad fundada en el artículo 14 de la Constitución, esto es, en el principio de igualdad ante la ley.

Un primer argumento en esta línea, dice la sentencia, es la alegación de la desigualdad producida por el hecho de que unos mismos daños personales o corporales reciban un tratamiento jurídico distinto en función de la 
mera circunstancia de haberse o no producido como consecuencia de la circulación de vehículos a motor.

El Tribunal sale al paso de esta alegación, diciendo en primer lugar:

«Cabe decir a este respecto que de la Constitución no se deriva que el instituto de la responsabilidad civil extracontractual tenga que ser objeto de un tratamiento normativo uniforme e indiferenciado ni, como es obvio, la Norma fundamental contiene una prohibición por la que se impida al legislador regular sus contenidos, adaptándolos a las peculiaridades de los distintos contextos en que se desenvuelven las relaciones sociales. En efecto, aun asumiendo dialécticamente la relación comparativa que se nos propone (distinta reparación cuantitativa de unos mismos daños personales, según se hubiesen o no producido en el ámbito de la circulación de vehículos a motor), es patente que ese tratamiento jurídico diferenciado no introduce desigualdad alguna entre las personas, cuyo trato discriminatorio es lo que proscribe el derecho a la igualdad que reconoce el art. $14 \mathrm{CE}$. En efecto, el legislador ha establecido una diversidad de regímenes jurídicos especiales en materia de responsabilidad civil extracontractual que se aplica a todos por igual, respondiendo así a una tendencia de signo opuesto a la etapa de la codificación, que da lugar a un Derecho de daños constituido por singulares ordenaciones que coexisten con el viejo núcleo de la responsabilidad civil por culpa contenido en el art. 1902 y siguientes del Código Civil».

A partir de aquí, la sentencia concluye que

«...la concreta regulación especial o diferenciada que se cuestiona no se ha articulado a partir de categorías de personas o grupos de las mismas, sino en atención exclusivamente al específico ámbito o sector de la realidad social en que acaece la conducta o actividad productora de los daños. Se opera así en función de un elemento objetivo y rigurosamente neutro, que explica por qué esa pluralidad de regímenes jurídicos especiales se aplica por igual a todos los ciudadanos, es decir, a todos los dañados, sin que implique, directa o indirectamente, un menoscabo de la posición jurídica de unos respecto de la de otros».

A continuación, la sentencia alude a otro posible motivo o causa de desigualdad, esto es, la consistente en el diverso tratamiento jurídico que, a través del sistema de baremo previsto en la Ley, se produce entre los daños personales o corporales, sometidos a una cuantía de indemnización máxima, y los daños en las cosas, cuya reparación no está sujeta a límites cuantitativos. En relación con este extremo, dice:

«También ahora ha de reconocerse que, con independencia del grado de acierto de esa decisión del legislador, la regulación legal se aplica por igual a todas las personas y en todas las circunstancias, sin que se consta- 
te la presencia de factores injustificados de diferenciación entre colectivos diversos».

Por lo que se refiere a la aducida vulneración del derecho de igualdad, supuestamente producida porque el sistema de valoración de daños personales mediante baremo genera un tratamiento igual de supuestos diversos, la resolución recuerda que

«...es doctrina reiterada y constante de este Tribunal que el derecho a la igualdad del art. 14 de la Constitución no consagra un derecho a la desigualdad de trato (STC 114/1995, de 6 de julio, F. 4), ni ampara la falta de distinción entre supuestos desiguales, por lo que no existe 'ningún derecho subjetivo al trato normativo desigual' (STC 16/1994, de 20 de enero, F. 5), siendo ajena al ámbito de este precepto constitucional la llamada 'discriminación por indiferenciación' (STC 308/1994, de 21 de noviembre, F. 5). En definitiva, 'el principio de igualdad no puede fundamentar un reproche de discriminación por indiferenciación' (STC 164/1995, de 13 de noviembre, F. 7) por lo que tampoco puede acogerse, desde esta perspectiva, la tacha de inconstitucionalidad así formulada».

5. A renglón seguido, la sentencia aborda la cuestión de inconstitucionalidad que razonaba en torno al artículo 9.3 (interdicción de la arbitrariedad de los poderes públicos), en relación con el «valor justicia» del artículo 1.

La resolución arranca en este punto de la afirmación siguiente:

«El valor justicia del art. 1.1 CE no puede, pues, identificarse unilateralmente con particulares modos de entender lo justo, ni con una forma de fiscalización de la constitucionalidad de la ley en atención a los resultados. Más bien ha de ser considerado como un concepto tendencialmente abierto y plural. Por ello, este valor superior del ordenamiento operará como un canon complementario, en concurrencia con otros factores de ponderación y, muy especialmente, en relación con el principio de interdicción de la arbitrariedad en su proyección sobre el legislador, principio este último que, con cita del art. 9.3 CE, también se considera vulnerado en los Autos de planteamiento de las presentes cuestiones de inconstitucionalidad, y cuyo examen abordamos a continuación».

Esta idea se pone en relación con la doctrina constitucional precedente de que «la ley es arbitraria en el supuesto de que careciera de toda explicación racional».

Sobre estas bases, el Tribunal rechaza una primera perspectiva de la cuestión, según la cual el sistema legal de valoración tasada sería arbitraria. Dice al respecto la resolución:

«Existen poderosas razones para justificar objetivamente un régimen jurídico específico y diferenciado en relación con los daños producidos 
como consecuencia de la circulación de vehículos a motor. Así, la alta siniestralidad, la naturaleza de los daños ocasionados y su relativa homogeneidad, el aseguramiento obligatorio del riesgo, la creación de fondos de garantía supervisados por la Administración (Consorcio de Compensación de Seguros), y, en fin, la tendencia a la unidad normativa de los distintos ordenamientos de los Estados miembros de la Unión Europea, son factores concurrentes perfectamente susceptibles de ser valorados por el legislador y que justifican suficientemente y hacen plausible la opción legislativa finalmente acogida, en cuanto sistema global».

En segundo término, el Tribunal vuelve de nuevo sobre el reproche consistente en que el sistema legal de baremación se limita al ámbito de daños a las personas, con exclusión de los ocasionados en los bienes. Lo rechaza la sentencia, diciendo:

«Los daños en las cosas no ofrecen especiales dificultades en orden a su valoración y cuantificación, puesto que son daños producidos en bienes que se encuentran en el tráfico comercial y que, como tales, cuentan con un valor-precio susceptible de ser objetivamente evaluado con arreglo a criterios ciertos que determina el mercado. Obviamente, no puede decirse lo mismo respecto de los daños a las personas o daños corporales, cuya traducción a valores de mercado, por ser res extra commercium, depende de pautas ajenas a la mera consideración económica, mucho más estimativas y difíciles de objetivar. Dificultad en la valoración y en la cuantificación que se muestra en toda su intensidad cuando se trata de compensar, mediante el pago de una indemnización, el denominado daño moral.

No es irrazonable, por lo tanto, que el legislador, en atención a la reseñada circunstancia, haya considerado conveniente diferenciar el modo en que deban valorarse los daños causados en los bienes y los estrictamente personales. Para la determinación cuantitativa de los primeros se cuenta con los criterios objetivos que suministra el mercado y que pueden ser objeto de concreta prueba en el proceso. Sin embargo, no existen referentes con parecido grado de objetivación que permitan calcular el quantum dinerario que, como remedio compensatorio, corresponde a la víctima por el daño personal inferido. Esta ausencia de criterios externos que sirvan de pauta determinante para la valoración del daño, sobre todo en lo que atañe a los daños morales, justifica que el legislador establezca los criterios normativos necesarios para garantizar un mínimo de homogeneidad y, por tanto, de paridad en el resarcimiento de los daños personales, tal como señala el punto 7 del apartado primero del Anexo, en su inciso inicial».

No obstante, la sentencia declara la justificación del reproche de arbitrariedad en cuanto a la aplicabilidad del sistema de valoración en el caso en el que concurre culpa exclusiva del conductor causante del accidente; culpa relevante y, en su caso, judicialmente declarada. En este sentido, la resolución razona así: 
«Como hemos indicado, la Ley cuestionada conforma un régimen jurídico de responsabilidad civil de común aplicación tanto a los casos de responsabilidad por creación de riesgo u objetiva, como a aquellos otros en que el daño tiene por causa una acción u omisión culposa del conductor del vehículo a motor. Partiendo de este dato, ha de afirmarse que la falta de individualización de los indicados perjuicios económicos, a que conduce la aplicación de la tabla $\mathrm{V}$ del Anexo, no produce ningún resultado jurídicamente arbitrario o carente de justificación racional cuando se proyecta sobre supuestos en los que el daño personal causado es consecuencia de la responsabilidad civil exigible por el riesgo creado, o peligro que per se comporta la utilización de vehículos a motor. En efecto, en este particular contexto regido por criterios de responsabilidad cuasiobjetiva, al que hace expresa referencia el art. 1.1 de la Ley cuestionada, no cabe, con base en el art. 9.3 CE, formular reparo o tacha de inconstitucionalidad oponible al legislador por el hecho de que éste, atendidas las circunstancias concurrentes (entre las que destacan el aseguramiento obligatorio y la socialización de la actividad potencialmente dañosa), haya establecido criterios objetivados para la reparación del daño, con la consiguiente restricción de sus posibilidades de individualización, configurando así un sistema de compensación pecuniaria a favor de las víctimas, basado en el sometimiento de los perjuicios económicos derivados del daño personal a topes o límites cuantitativos.

Por el contrario, cuando concurre culpa exclusiva del conductor causante del accidente, relevante y, en su caso, judicialmente declarada, ya no cabe acoger tal justificación. En este otro ámbito, el presupuesto obligado de partida viene constituido por el hecho de que los bienes lesionados por el acto antijurídico son del máximo rango constitucional ('ex' art. $15 \mathrm{CE}$ ), y que la limitación indemnizatoria establecida por el sistema legal comporta, correlativamente, una desprotección de los aludidos bienes de la personalidad».

Razonamiento que lleva a la Sala a otro argumento, determinante de su fallo:

«Así pues, resulta manifiestamente contradictorio con este esquema de imputación que, cuando concurre culpa exclusiva del conductor, la víctima tenga que asumir parte del daño que le ha sido causado por la conducta antijurídica de aquél. Es ésta una consecuencia que no se acomoda al mandato de interdicción de la arbitrariedad del art. 9.3 CE, en cuanto el sistema valorativo utiliza el título de imputación de la culpa siempre en sentido favorable o beneficioso para quien, incurriendo en un ilícito, produjo el daño personal y los consiguientes perjuicios económicos a él anudados; máxime cuando la conducta antijurídica determinante del daño, lesiona o menoscaba bienes de tanta relevancia constitucional como son la integridad física y moral de las personas, reconocidos en el art. 15 de la Constitución». 
Pero la sentencia no restringe su tacha de inconstitucionalidad (la parcial que vengo señalando) al artículo 9.3, sino que la funda también en la alegada vulneración del artículo 24.1 (derecho a la tutela judicial efectiva), expresada en la afirmación de que el baremo no permite a la víctima del accidente de circulación acreditar procesalmente que las pérdidas patrimoniales producidas como consecuencia de la lesión de los derechos corporales son, en el caso concreto, superiores a las fijadas por el legislador.

De ahí que, ya al final de su texto, la resolución diga:

«La configuración normativa de la analizada tabla V, referida a la indemnización de las lesiones temporales, determina que la pretensión resarcitoria de las víctimas o perjudicados no pueda ser efectivamente satisfecha en el oportuno proceso, con la consiguiente vulneración de su derecho a una tutela judicial efectiva (art. 24.1 CE).

Al tratarse, en suma, de un sistema legal de tasación de carácter cerrado que incide en la vulneración constitucional antes indicada, y que no admite ni incorpora una previsión que permita la compatibilidad entre las indemnizaciones así resultantes y la reclamación del eventual exceso a través de otras vías procesales de carácter complementario, el legislador ha establecido un impedimento insuperable para la adecuada individualización del real alcance o extensión del daño, cuando su reparación sea reclamada en el oportuno proceso, con lo que se frustra la legítima pretensión resarcitoria del dañado, al no permitirle acreditar una indemnización por valor superior al que resulte de la estricta aplicación de la referida tabla $\mathrm{V}$, vulnerándose de tal modo el derecho a la tutela judicial efectiva que garantiza el art. 24.1 CE».

6. La resolución razona también sobre el argumento de que el sistema legal infringe la exclusiva potestad jurisdiccional, tal y como se halla configurada por el artículo 117.3 de la Carta Magna. Era, sin duda, el punto más «sensible» para los jueces españoles.

A tal efecto, dice la resolución:

«Pues bien, el anterior reproche de inconstitucionalidad no puede prosperar. Es cierto que el sistema de valoración de los daños corporales previsto en el art. 1 y en el Anexo de la Ley 30/1995, en su designio de asegurar mayores dosis de igualdad y seguridad jurídicas, ha reducido las posibilidades de libre apreciación del juzgador en función de los diversos materiales probatorios aportados al proceso, que era, precisamente, el elemento principal sobre el que descansaba el modelo de estimación y cuantificación de los daños y perjuicios a las personas anteriormente existente.

Ahora bien, del principio de exclusividad de Jueces y Magistrados en el ejercicio de la potestad jurisdiccional (art. 117.3 CE) no puede inferirse la existencia de una correlativa prohibición impuesta al legislador, por 
la que se condicione su libertad de configuración para elegir el nivel de densidad normativa con que pretende regular una determinada materia».

C. Constitucionalidad de un régimen de responsabilidad objetiva. Y, también, del principio de inversión de la carga de la prueba en un 'sistema' de responsabilidad por culpa

1. Que yo sepa, no se ha planteado nunca ante el TC, de manera directa, la cuestión de si un régimen legal de responsabilidad objetiva se ajusta o no a la Constitución. Me refiero a una fórmula de imputación de responsabilidad que se encuentra ampliamente establecida en los ordenamientos contemporáneos; en España, como casos más notables, los de daños derivados de la navegación aérea, de la circulación de vehículos a motor, de la explotación de la energía nuclear, de la caza, de determinados servicios, del uso o consumo de productos defectuosos, etc.

Los reparos que desde otros puntos de vista, hoy superados (por ejemplo, el ideológico según el cual «se es responsable porque se es culpable»), podría suscitar la responsabilidad objetiva (o sin culpa), no parecen encontrar soporte ni en los derechos ni en los principios constitucionalmente reconocidos; ni siquiera, como luego veremos, en el de presunción de inocencia.

Entiendo que se da por sentado (y así mueve a pensar la sentencia del TC sobre la eventual inconstitucionalidad del baremo del automóvil) que el legislador goza de libertad para establecer ese régimen de responsabilidad sin culpa, en atención a derechos o intereses que se juzgan superiores; señaladamente, los de los consumidores. La circunstancia de que de ordinario la responsabilidad objetiva esté acompañada de una fórmula de seguro obligatorio parece soslayar toda sospecha de inconstitucionalidad. Y cuando la «solución» del seguro obligatorio no existe, parece razonable pensar que cualquier reparo de inconstitucionalidad, respecto al causante del daño, se disipa a la luz de dos ideas: el que se aprovecha económicamente de una actividad debe pechar con sus consecuencias (el cuius commoda, eius incommoda) y, además, debe contar con la carga -que razonablemente se espera de cualquier sujeto sensato- de concertar un seguro voluntario.

2. Más peliaguda es la cuestión de la constitucionalidad de la inversión de la carga de la prueba (correlato procesal de un principio de presunción de culpa), hoy firmemente asentada en la jurisprudencia -si no en la propia legislación- en ámbitos de responsabilidad gobernados por el criterio de imputación por culpa (la llamada «subjetivista»).

Tal principio de presunción de culpa en el causante del daño se encuentra hoy, y desde hace décadas, sólidamente arraigado en la jurisprudencia civil española. Muy pocos casos quedan fuera de su radio de acción; casi exclusivamente los derivados de actividades no inspiradas por el ánimo de lucro. 
También que yo sepa, el Tribunal Constitucional español no ha tenido oportunidad de manifestarse al respecto de forma directa (sí de manera colateral, al referirse al principio constitucional de presunción de inocencia, al que luego me referiré). Lo que llama un tanto la atención, porque el criterio jurisprudencial en cuestión choca abiertamente, a mi entender, con el principio procesal (¿quizá «constitucional»?) de que corresponde al actor la carga de probar la certeza de los hechos de los que ordinariamente se desprenda el efecto jurídico correspondiente a las pretensiones de la demanda ${ }^{27}$.

Ahora bien, quizá pudiera solventarse cualquier tacha de inconstitucionalidad con el argumento de que la presunción de culpa es iuris tantum, esto es, susceptible de prueba en contrario, así como -de nuevo- con la idea de que la presunción de culpa en el terreno de la responsabilidad civil no constituye quiebra de la presunción de inocencia constitucionalmente reconoci$\mathrm{da}^{28}$. Por otro lado, puede sostenerse que la concurrencia de culpa no es un hecho cuya prueba incumbe al perjudicado, sino una quaestio iuris.

\section{Aspectos constitucionales de la indemnización del llamado 'daño moral'}

Ahora acudo a la expresión «daño moral» en una acepción muy restringida, llamando así al que sufre una persona como consecuencia de un atentado a su honor, a su intimidad o a su imagen.

Ya hemos visto antes cómo el TC español, en su sentencia sobre el baremo del automóvil, alude con razón a la dificultad que entraña la traducción a términos económicos de ese tipo de lesiones. Y si me ocupo ahora de este extremo es porque el TC tuvo oportunidad de manifestarse sobre el significado «constitucional» de una resolución judicial que concedió una indemnización muy exigua a quien había sufrido un atentado a su intimidad y a su imagen. Se trataba de un caso que fue muy notorio en nuestro país, porque la víctima era una mujer de gran relieve en la «vida de sociedad» española (por así decirlo, la alta sociedad). Una antigua empleada de su hogar había hecho unas declaraciones a una revista, revelando intimidades de su también antigua empleadora. No parecían ser excesivamente ofensivas; de hecho, la Sala Primera del Tribunal Supremo dijo que constituían sólo «una propalación de chismes de escasa entidad, que en algún caso pudieran servir como base para resolver el contrato laboral de empleo del hogar, pero nunca para estimarlos como un atentado grave y perjudicial a la intimidad de una persona».

La ofendida planteó demanda contra la empleada, dictándose en última instancia sentencia de la Sala Primera del Tribunal Supremo por la que se

${ }^{27}$ Acudo a las palabras del artículo 217.2 de la Ley de Enjuiciamiento civil española.

${ }^{28}$ De hecho, no sé de ningún autor español que se haya planteado dudas sobre una posible inconstitucionalidad de la inversión de la carga de la prueba. Por citar doctrina reciente y de máxima solvencia, DíEz-PICAZo, Derecho de daños, Civitas, Madrid, 1999. 
desestimó la demanda; el argumento era precisamente el de la escasa entidad de los «chismes».

Formuló recurso de amparo la demandante, dictándose por el TC sentencia de 5 de mayo de 2000 por la que se reconocía haber habido lesión del derecho a la intimidad personal y familiar de la recurrente y se anulaba la sentencia del Tribunal Supremo.

La Sala Primera del Tribunal Supremo dictó nueva sentencia, de 20 de julio de 2000, en la que se estableció una condena de 25.000 pesetas, algo así como 190 dólares USA.

Recurrió de nuevo en amparo la agraviada, evidentemente por considerar ignominiosa la condena de 25.000 pesetas. Su posición social y económica permiten pensar que no era una acción en busca de dinero, según expresión conocida de los juristas norteamericanos.

El Tribunal Constitucional, en sentencia de 17 de setiembre de 2001, otorgó el amparo solicitado por la demandante, reconoció que se había vulnerado el derecho a su intimidad personal y familiar y acordó restablecerla en su derecho; se declaró la nulidad de la segunda sentencia de la Sala Primera del Tribunal Supremo, estableciendo el TC directamente una indemnización en favor de la demandante por un importe de 10.000.000 de pesetas, que era la que había acordado la Audiencia Provincial.

En lo que aquí interesa, procede reproducir unos fragmentos de la sentencia del TC, en los que se excluye que la indemnización de este daño moral pueda quedar reducida a un carácter simbólico, por reducido o exiguo. Dice la resolución:

«Respecto a la indemnización fijada por la Sentencia recurrida es cierto que este Tribunal ha declarado que, en principio, la fijación de una u otra cuantía no es susceptible de convertirse en objeto de vulneración autónoma de los derechos fundamentales, en este caso del derecho a la intimidad. Pero no es menos cierto que también hemos declarado que 'la Constitución protege los derechos fundamentales... no en sentido teórico e ideal, sino como derechos reales y efectivos' (STC 176/1988, de 4 de octubre, F. 4). Como indicamos en la STC 12/1994, de 17 de enero, F. 6, los arts. 9.1, 1.1 y 53.2 CE impiden que la protección jurisdiccional de los derechos y libertades se convierta en 'un acto meramente ritual o simbólico'. Así lo proclaman, en el ámbito propio del amparo constitucional, los arts. 1, 41 y 55 de nuestra Ley Orgánica. Desde esta perspectiva existen motivos para afirmar que una indemnización de 25.000 pesetas resulta insuficiente para reparar el derecho a la intimidad personal y familiar de la recurrente. Sin embargo, desde la perspectiva de la lesión de ese derecho fundamental la cuestión de mayor trascendencia no es ésta, sino el apartamiento de la Sentencia recurrida de los criterios fijados por la STC $115 / 2000$ en orden a delimitar el alcance del derecho y fijar la indemnización.

Pues bien, analizando la cuestión desde esta perspectiva cabe concluir que, en efecto, al revisar la cuantía de la indemnización fijada por la 
Audiencia Provincial la Sentencia ahora impugnada partió de un entendimiento del derecho a la intimidad que no se ajusta a la interpretación que de tal derecho fundamental realizó este Tribunal en su Sentencia, y que vincula a todos los Jueces y Tribunales que integran el Poder Judicial (art. 5.1 LOPJ). El Tribunal Supremo valora la cuantía de la indemnización con base en el carácter 'insignificante' de determinadas frases del reportaje ('granos que le salen en la cara..., determinada agenda de piel de cocodrilo..., ropa que posee...'), argumento que ya utilizó en su primera Sentencia de casación, en la que declaró que tales datos, calificados de 'chismes de escasa entidad', no podían reputarse como gravemente atentatorios a la intimidad. Se aparta así de los criterios fijados en la STC 115/2000, ya que, en primer lugar, como se desprende del tenor literal de su fundamento jurídico 5 antes citado, la vulneración del derecho a la intimidad no derivó únicamente del hecho de haberse revelado datos sobre 'los granos', 'la agenda' y 'la ropa' de la recurrente, sino de haber desvelado otros datos de su vida personal y familiar de mucha mayor entidad. Se ponderó, además, según consta en el fundamento jurídico 6, el carácter cualificado de la vulneración derivado del hecho de que la divulgación de los datos había sido realizada quebrantando el deber de secreto impuesto a las personas que conviven en el hogar de una persona por razones laborales. Por otra parte, en la STC 115/2000 se declaró que la vulneración del derecho a la intimidad no podía hacerse depender de la insignificancia de algunas de las expresiones vertidas en el curso de dicho reportaje, ya que revestía la trascendencia propia de la relevancia constitucional del derecho fundamental afectado; y, aunque en el F. 8 se afirmase con carácter general que la gravedad atentatoria de los datos revelados podía ser tenida en cuenta para modular la responsabilidad de quien lesiona el derecho, por supuesto eso no significa que al fijar la indemnización pueda desconocerse la premisa de la relevancia constitucional del derecho afectado y la correlativa exigencia de una reparación acorde con el relieve de los valores e intereses en juego.

Por ello, al no considerar la Sentencia impugnada, ni aun tras el enjuiciamiento realizado en la STC 115/2000, que la revelación de tales datos constituyó el núcleo de la intromisión ilegítima efectuada en la intimidad personal y familiar de la demandante de amparo, y reiterar de nuevo una minusvaloración del quebranto sufrido por el derecho fundamental afectado en función del pretendido 'carácter insignificante' de algunas frases del reportaje publicado en la revista Lecturas, la Sentencia frente a la cual ahora se demanda amparo realiza una interpretación que, lejos de reparar el derecho vulnerado, lesiona de nuevo el derecho a la intimidad (art. 18.1 $\mathrm{CE}$ ), menoscabando así la eficacia jurídica de la situación subjetiva declarada en nuestra precedente Sentencia» ${ }^{29}$.

${ }^{29}$ Debo señalar que dos Magistrados de la Sala Segunda del TC, compuesta por seis miembros, discreparon de la fijación directa por el Tribunal Constitucional de la indemnización, considerando que lo procedente habría sido devolver las actuaciones al Tribunal Supremo. 


\section{E. El problema de los 'daños punitivo'. Y la indemnización consistente en el} beneficio del dañador

1. No es preciso resaltar ni documentar el interés que en el plano doctrinal suscita, en los países del civil law, la figura de los llamados daños punitivos (entre otras denominaciones), tan afincados en algunos países del common law, sobre todo Estados Unidos.

Pero no me voy a referir a la cuestión de la bondad o maldad del concepto, o de su aplicación práctica, sino a dos posibles aspectos en los que la figura podría ser contemplada, desde el punto de vista constitucional.

El primero de esos aspectos es el relativo a si podría tener acomodo en nuestra Constitución, o en otra inspirada en una similar cultura jurídica, una hipotética formulación legal del tipo de «indemnización» que los daños punitivos constituyen.

Y en íntima conexión con ese primer punto de vista está el segundo, que es el de la posibilidad de ejecutar una sentencia comprensiva de daños punitivos en un Estado cuyo ordenamiento no los reconoce.

Ambas preguntas, como es obvio, están radicalmente vinculadas con el carácter que, según la tradición jurídica, se atribuya en un determinado ordenamiento a las reglas de responsabilidad civil. Esto es, si se les reconoce sólo una función de indemnización, o si también cabe atribuirles una finalidad punitiva, o una de prevención, u otra de disuasión, etc.

La doctrina española no parece aceptar, en general, que los daños punitivos se acomoden al concepto que de la responsabilidad civil tenemos en nuestro país ${ }^{30}$.

Pero, puesto que contamos con el ejemplo de un ordenamiento jurídico, el alemán, inspirado en principios (en esta materia) similares al nuestro, creo que no es inoportuno dar a conocer el criterio del Tribunal Federal de Alemania sobre el problema.

Me refiero a la sentencia del Tribunal Federal de Justicia alemán de 4 de junio de $1992^{31}$.

Los orígenes del caso resuelto por el Tribunal Federal se encuentran en Stockon, California, lugar donde residían el demandante y el demandado. Ambos poseían la nacionalidad norteamericana; el demandado, además, tenía la nacionalidad alemana. En mayo de 1984, el demandado -que había

${ }^{30}$ Escribe sobre la cuestión Reglero CAmpos en el Tratado que antes he citado, pp. 76 ss. Yo lo hice brevemente en mi libro Algunas previsiones sobre el futuro de la responsabilidad civil (con especial atención a la reparación del daño), Civitas, Madrid, 1995, pp. 69ss.

${ }^{31}$ Tomo una valiosa información de VADILLO RoBREDO, «Reconocimiento y ejecución en Alemania de sentencias extranjeras de daños punitivos (Comentario a la decisión del Tribunal Federal de Justicia alemán de 4 de junio de 1992)», en Estudios de Deusto, julio-diciembre, 1997, pp. 203-ss. Trabajo de notable interés para conocer algunos detalles del régimen de los daños punitivos. 
sido sentenciado por un tribunal norteamericano a prisión por abuso sexual de un menor (el demandante)- abandonó los Estados Unidos. Desde ese momento, vivió en Alemania, donde poseía propiedades.

El Tribunal Superior del Estado de California y del Distrito de San Joaquín, el 24 de abril de 1985, condenó al demandado a abonar a la víctima una indemnización de 750.260 dólares. De las transcripciones del proceso se desprende que el veredicto estaba basado en la ofensa sexual cometida contra el demandante, quien en el momento de la ofensa tenía 14 años. La indemnización se compuso de 260 dólares por gastos médicos pasados, 100.00 dólares por gastos médicos futuros, 50.000 dólares por gastos de colocación de la víctima, 200.000 dólares por ansiedad, dolor, sufrimiento y daños generales de esta naturaleza y 400.000 dólares por daños punitivos. Al abogado de la víctima se le concedió el 40\% (300.104 dólares) del total de la indemnización final recibida por su cliente, como honorarios.

Ante el Bundesgerichtshof se presentó, en apelación, el reconocimiento y la ejecución de la sentencia del Tribunal Superior del Estado de California.

El Tribunal de Distrito había decidido que en este caso no había impedimento para una orden de ejecución de sentencia, más los intereses. En respuesta a la apelación del demandado, el Tribunal de Apelación de Düsseldorf mantuvo la orden de ejecución de la sentencia, pero redujo la indemnización a la cantidad de 272.325 dólares. Las dos partes apelaron la sentencia. El Tribunal Federal de Justicia decidió que la cantidad correspondiente a los daños punitivos (400.000 dólares) no podía ser ejecutada en Alemania; sobre el resto de la indemnización se emitió la orden de ejecución.

Quiere decir que, en este caso, el Tribunal Federal de Justicia decidió que la indemnización de daños punitivos constituía un ataque al orden público sustantivo conforme al 328(1)4 del Código de procedimiento civil alemán.

Repito que en la sentencia del Tribunal Superior de California se indemnizó a la víctima con 400.000 dólares por daños punitivos. El Tribunal de Distrito alemán decidió que cabía la orden de ejecución sobre todo el veredicto del Tribunal Superior, más los intereses. Tras la apelación del demandado, el Tribunal de Apelación de Düsseldorf sostuvo, como decía, la orden de ejecución en la cantidad de 275.325 dólares y anuló el resto. Su interpretación sobre esta cuestión fue que la orden de ejecución sólo podía ser emitida sobre la suma requerida para cubrir los costes legales, aunque dicha suma estaba supeditada al examen del orden público. El examen de orden público tuvo como resultado que, en lugar del $40 \%$ de la indemnización total que estableció el Tribunal Superior de California como honorarios de abogado, sólo se reconociese el $25 \%$ de la indemnización de daños compensatorios recibida por la víctima (55.065 dólares).

En lo que interesa al extremo que ahora nos ocupa (puesto que hubo otros que ahora no vienen a cuento), considero de gran interés reproducir los razonamientos del Tribunal Federal para no aceptar la ejecución en Alemania de los daños punitivos que había establecido el Tribunal norteamericano: 
«Uno de los principios fundamentales del Derecho alemán es el principio de 'proporcionalidad', el cual surge del Estado constitucional y es válido también en el Derecho civil... En el Derecho civil, la atención que se presta a la compensación en la valoración de los daños, entre otras cosas, tiene este principio en cuenta: a menudo, la única intención apropiada de la acción civil, tomada en respuesta a un acto ilícito, es la de compensar por los efectos de ese acto sobre las circunstancias financieras de las partes directamente afectadas. Las reglas de procedimiento y las reglas sobre la prueba para las acciones de esta clase permiten a las partes ejercer una influencia variada y dominante sobre el resultado, y han sido diseñadas con este propósito. Las acciones civiles norteamericanas están gobernadas por reglas similares...

Las sanciones que intentan ser punitivas o disuasorias $-\mathrm{o}$, por ejemplo, proteger el derecho y el orden público- son, según la interpretación alemana del Derecho, parte del monopolio de castigo ejercido por el Estado. Es él quien ejercita este monopolio en interés del público en un proceso especial, en el que por un lado la investigación oficial intenta proveer de una mejor garantía para que la decisión sustantiva sea exacta, mientras que por otro lado asegura una mayor protección para los derechos del demandado. Desde un punto de vista local, sería inaceptable imponer, en un juicio civil, el pago de una considerable suma de dinero, la cual no intenta ser compensación por los daños, sino que es calculada esencialmente según el interés público y puede ser impuesta junto con el castigo criminal por la misma ofensa...

De hecho, esto es lo que ha ocurrido en el caso presente. La indemnización impuesta es mayor que el total de todas las sumas concedidas para compensar por el daño causado. Aun el total de todos los costes legales supondría sólo una tercera parte de los 'daños punitivos'. No existe prueba de otros daños por los que se deba conceder compensación. El efecto de la orden de ejecución en el demandado sería, por lo tanto, excesivo.

Los daños punitivos impuestos bajo el poder discrecional del tribunal, los cuales no tienen una relación firme con el daño sufrido y algunos de los cuales son extremadamente altos, han contribuido a un importante aumento en la carga de las indemnizaciones en la economía como un todo. Dicha carga ha alcanzado ahora el límite del riesgo calculable y asegurable...

...Por esta razón, la ejecución de una reclamación de indemnización por daños -superior a la compensación de todas las lesiones patrimoniales y extrapatrimoniales realmente sufridas-constituiría en sí misma un resultado inaceptable...

La ejecución en Alemania está, por lo tanto, excluida. No es necesario determinar si la ejecución de la indemnización de daños también contraviene la ley y el orden alemán en otras bases. En particular, no hay necesidad de determinar si las condiciones para la imposición de un veredicto de daños punitivos, cuyas condiciones son difíciles de estipular, y la cantidad de la indemnización deben valorarse según las bases del artículo 
103.2 de la Constitución de Alemania, o si la condena a este pago, así como la pena criminal, constituiría, desde el punto de vista alemán, una violación de la prohibición de castigo múltiple (artículo 103.3 de la Constitución alemana)».

Estimo que razones semejantes a las invocadas por el Tribunal Federal alemán serían las que utilizaría un tribunal español ante un caso similar. Pero la cuestión, que algún día se nos planteará, está por resolver.

2. Distinto conceptualmente de la figura de los daños punitivos es el caso en que una ley impone, en el supuesto de daño extracontractual, una «indemnización» consistente en el beneficio que el dañador hubiere obtenido con su conducta lesiva ${ }^{32}$.

Aunque los criterios tradicionales en materia de indemnización del daño buscan eso, la reparación de la víctima y nada más, nuestro Derecho conoce casos en los que alguna ley dispone una fórmula de «indemnización» consistente, según decía, en el beneficio patrimonial del dañador.

Así, el artículo 9 de la Ley de protección civil del derecho al honor, a la intimidad personal y familiar y a la propia imagen, de 5 de mayo de 1982, dispone en su artículo 9, apartado 3:

«La existencia de perjuicio se presumirá siempre que se acredite la intromisión ilegítima. La indemnización se extenderá al daño moral que se valorará atendiendo a las circunstancias del caso y a la gravedad de la lesión efectivamente producida, para lo que se tendrá en cuenta, en su caso, la difusión o audiencia del medio a través del que se haya producido. También se valorará el beneficio que haya obtenido el causante de la lesión como consecuencia de la misma» ${ }^{33}$.

De otro lado, y siguiendo en parte criterios ya establecidos en las Leyes que se modificaban, la Ley de 5 de junio de 2006, que amplía los medios de tutela de los derechos de propiedad intelectual e industrial y establece normas procesales para la aplicación de diversos reglamentos comunitarios,

\footnotetext{
32 También me cuidé brevemente de esta hipótesis en el libro antes citado, Algunas previsiones..., pp. 64-ss.

${ }^{33}$ Como hace notar Reglero CAmpos, Tratado..., p. 96, la sentencia del TC de 17 de setiembre de 2001, antes citada, aceptó implícitamente la constitucionalidad de este concepto de «indemnización» consistente en el beneficio obtenido por el causante de la lesión. Más aún, el TC reprochó al Tribunal Supremo el no haber tenido en cuenta en aquel caso los beneficios obtenidos por la empresa editora de la revista en la que se había publicado el reportaje ofensivo. El TC señaló que en las actuaciones seguidas en primera instancia quedaba reflejado que se había producido un incremento de tirada de la revista, incremento que coincidió con la injerencia ilegítima en la intimidad de la demandante.
} 
modificó parcialmente la Ley de propiedad intelectual, la Ley de patentes, la Ley de marcas y la Ley de protección jurídica del diseño industrial ${ }^{34}$.

En cuanto a la Ley de propiedad intelectual, su artículo 140 queda redactado así:

«Artículo 140. Indemnización.

1. La indemnización por daños y perjuicios debida al titular del derecho infringido comprenderá no sólo el valor de la pérdida que haya sufrido, sino también el de la ganancia que haya dejado de obtener a causa de la violación de su derecho. La cuantía indemnizatoria podrá incluir, en su caso, los gastos de investigación en los que se haya incurrido para obtener pruebas razonables de la comisión de la infracción objeto del procedimiento judicial.

2. La indemnización por daños y perjuicios se fijará, a elección del perjudicado, conforme a alguno de los criterios siguientes:

a) Las consecuencias económicas negativas, entre ellas la pérdida de beneficios que haya sufrido la parte perjudicada y los beneficios que el infractor haya obtenido por la utilización ilícita.

En el caso de daño moral procederá su indemnización, aun no probada la existencia de perjuicio económico. Para su valoración se atenderá a las circunstancias de la infracción, gravedad de la lesión y grado de difusión ilícita de la obra.

b) La cantidad que como remuneración hubiera percibido el perjudicado, si el infractor hubiera pedido autorización para utilizar el derecho de propiedad intelectual en cuestión.

3. La acción para reclamar los daños y perjuicios a que se refiere este artículo prescribirá a los cinco años desde que el legitimado pudo ejercitarla».

Por lo que respecta a la Ley de patentes, su artículo 66 queda redactado, en sus apartados 1 y 2 , de la siguiente forma:

«1. La indemnización de daños y perjuicios debida al titular de la patente comprenderá no sólo el valor de la pérdida que haya sufrido, sino también el de la ganancia que haya dejado de obtener el titular a causa de la violación de su derecho. La cuantía indemnizatoria podrá incluir, en su caso, los gastos de investigación en los que se haya incurrido para obtener

${ }^{34}$ Debe advertirse que esta Ley de 5 de junio de 2006 obedeció, entre otros motivos, al de trasponer al Derecho español la Directiva 2004/48/CE, del Parlamento Europeo y del Consejo, de 29 de abril de 2004, relativa al respeto de los derechos de propiedad intelectual, para garantizar un nivel de protección elevado, equivalente y homogéneo en el mercado interior. También debe advertirse que bajo la denominación de propiedad intelectual también se recojen en el Derecho comunitario los derechos que en el ordenamiento jurídico español se agrupan bajo la denominación de propiedad industrial. 
pruebas razonables de la comisión de la infracción objeto del procedimiento judicial.

2. Para fijar la indemnización por daños y perjuicios se tendrán en cuenta, a elección del perjudicado:

a) Las consecuencias económicas negativas, entre ellas los beneficios que el titular habría obtenido previsiblemente de la explotación de la invención patentada si no hubiera existido la competencia del infractor $y$ los beneficios que este último haya obtenido de la explotación del invento patentado.

En el caso de daño moral procederá su indemnización, aun no probada la existencia de perjuicio económico.

b) La cantidad que como precio el infractor hubiera debido pagar al titular de la patente por la concesión de una licencia que le hubiera permitido llevar a cabo su explotación conforme a derecho.

Para su fijación se tendrá en cuenta especialmente, entre otros factores, la importancia económica del invento patentado, la duración de la patente en el momento en que comenzó la violación y el número y clase de licencias concedidas en ese momento».

El artículo 43, apartados 1 y 2, de la Ley de marcas queda con la siguiente redacción:

«1. La indemnización de daños y perjuicios comprenderá no sólo las pérdidas sufridas, sino también las ganancias dejadas de obtener por el titular del registro de la marca causa de la violación de su derecho. El titular del registro de marca también podrá exigir la indemnización del perjuicio causado al prestigio de la marca por el infractor, especialmente por una realización defectuosa de los productos ilícitamente marcados o una presentación inadecuada de aquélla en el mercado. Asimismo, la cuantía indemnizatoria podrá incluir, en su caso, los gastos de investigación en los que se haya incurrido para obtener pruebas razonables de la comisión de la infracción objeto del procedimiento judicial.

2. Para fijar la indemnización por daños y perjuicios se tendrá en cuenta, a elección del perjudicado:

a) Las consecuencias económicas negativas, entre ellas los beneficios que el titular habría obtenido mediante el uso de la marca si no hubiera tenido lugar la violación y los beneficios que haya obtenido el infractor como consecuencia de la violación.

En el caso de daño moral procederá su indemnización, aun no probada la existencia de perjuicio económico.

b) La cantidad que como precio el infractor hubiera debido de pagar al titular por la concesión de una licencia que le hubiera permitido llevar a cabo su utilización conforme a derecho».

Por fin, el artículo 55 de la Ley de protección jurídica del diseño industrial queda, en sus apartados 1 y 2, con la siguiente redacción: 
«1. La indemnización de daños y perjuicios comprenderá no sólo las pérdidas sufridas, sino también las ganancias dejadas de obtener por el titular del diseño a causa de la violación de su derecho. El titular del diseño registrado también podrá exigir la indemnización del perjuicio causado al prestigio del diseño por el infractor, especialmente por una realización defectuosa de los productos ilícitamente comercializados, la realización defectuosa de las imitaciones o las condiciones en que haya tenido lugar su comercialización. Asimismo, la cuantía indemnizatoria podrá incluir, en su caso, los gastos de investigación en los que se haya incurrido para obtener pruebas razonables de la comisión de la infracción objeto del procedimiento judicial.

2. Para fijar la indemnización por daños y perjuicios se tendrá en cuenta, a elección del perjudicado:

a) Las consecuencias económicas negativas, entre ellas los beneficios que el titular habría obtenido de la explotación del diseño si no hubiera tenido lugar la violación de su derecho y los beneficios obtenidos por el infractor como consecuencia de la violación del derecho del titular del diseño registrado.

En el caso de daño moral procederá su indemnización, aun no probada la existencia de perjuicio económico.

b) La cantidad que como precio el infractor hubiera debido de pagar al titular del diseño por la concesión de una licencia que le hubiera permitido llevar a cabo la explotación del diseño conforme a derecho».

Si menciono todos estos preceptos que he citado es porque podría pensarse que las reglas legales en cuestión rompen con el principio de que la responsabilidad civil obedece sólo a una finalidad de indemnización; esto es, no a una función punitiva.

Sin embargo, creo que cualquier opinión en tal sentido debe descartarse, porque, si bien se mira, el criterio del beneficio del infractor se utiliza como elemento de cuantificación de un daño que, o no puede someterse a reglas objetivas de estimación, como puede ser el daño moral, o bien corresponde a conceptos de indemnización (sobre todo, el lucro cesante de la víctima) que es legítimo trasladar a un «capítulo» que libera al demandante de pruebas diabólicas, y a su vez muy objetivo, como es el de la ganancia económica o beneficio patrimonial obtenido por el infractor con su conducta dañosa.

No creo, pues, que en este extremo exista el más mínimo roce con la constitucionalidad.

\section{F. Responsabilidad civil y presunción de inocencia}

Se ha esgrimido frecuentemente ante los Tribunales civiles españoles la alegación de que la línea jurisprudencial de invertir la carga de la prueba y requerir - para que el demandado presunto responsable sea absuelto- que sea él quien demuestre no haber cometido la acción o, en su caso, no haber incurrido en omisión alguna de la diligencia debida en su actuar, opera en 
contra de la presunción de inocencia del artículo 24.2 de la Constitución española ${ }^{35}$.

El Tribunal Constitucional rechaza ese reproche de inconstitucionalidad, diciendo por ejemplo (sentencia de 13 de diciembre de 1993):

«Respecto de la vulneración del derecho a la presunción de inocencia la queja del recurrente carece de fundamento constitucional. Este derecho fundamental actúa siempre que deba adoptarse una resolución, judicial o administrativa, que se base en la condición o conducta de las personas y de cuya apreciación se derive un resultado punitivo, sancionador o limitativo de sus derechos [SSTC 13/1982, 36/1985], y por ello, no es aplicable a los supuestos de mera imposición de la responsabilidad civil en los que sólo se dilucida la imputación al responsable de un hecho productor o fuente de una obligación patrimonial de resarcimiento de daños y perjuicios derivada de un ilícito civil (art. 1.089 CC)».

El mismo criterio se ha formulado reiteradamente por la Sala de lo civil del Tribunal Supremo. Por citar una de las más recientes sentencias al respecto, la de 13 de febrero de 2003 declara:

«El octavo alega la infracción del artículo 24.2 de la Constitución Española por no haberse respetado el principio de presunción de inocencia. Este principio se aplica no sólo en el ámbito del Derecho penal, sino en todo campo del Derecho en que se contengan normas punitivas o sancionadoras, pero no cuando se trata de una cuestión de acreedor y deudor de una obligación nacida, en el presente caso, de acto negligente. Así la sentencia de 19 de junio de 1997 dijo claramente: "el principio de presunción de inocencia se aplica a todo el campo del Derecho pero sólo en caso de normas represivas, punitivas o sancionadoras; en general, para el Derecho civil: en principio, no contiene este tipo de normas, sino relativas a derechos o intereses privados, por lo que muy raramente es aplicable tal principio; en concreto, para el Derecho de obligaciones: se trata de acreedor y deudor, no de culpable o inocente, incluso en materia de responsabilidad extracontractual; en concreto, para el proceso civil: no cabe una resolución judicial que produzca un efecto jurídico desfavorable o condene a una carga perjudicial si no media prueba, valorada libremente por el Tribunal de instancia'. Lo cual es reiterado y aplicado específicamente a un caso de responsabilidad aquiliana, como el presente, por la sentencia de 12 de junio de 1998 que dice: 'la presunción de inocencia, no es aplicable al caso de la culpa extracontractual, habiendo de referirse en todo caso, a normas represivas, punitivas o sancionadoras, cuyo carácter no tienen los artículos 1902 y 1903 del Código Civil, pues la indemnización que contemplan es de significación reparadora o de compensación, para con-

${ }^{35}$ Me referí a este extremo en mi Tratado de responsabilidad civil, Civitas, Madrid, 1993, pp. 193-202. 
seguir que el patrimonio de la víctima quede, por efecto de la indemnización y a costa de los responsables del daño, en situación equivalente al que tenía antes de sufrirlo (SS. 20 de febrero de 1989, 25 de marzo de 1991, 7 de enero de 1992 y 2 de marzo de 1993, entre otras)'. Asimismo lo reiteran las sentencias de 28 de marzo de 2000, que recoge la doctrina jurisprudencial vertida en sentencias anteriores, y de 28 de junio de 2002, en un caso de obligación contractual».

G. La responsabilidad 'patrimonial' de las Administraciones públicas en la Constitución española. La 'posible' responsabilidad patrimonial del Estado legislador

1. Como he señalado antes, el único precepto de la Constitución que establece propiamente un principio de responsabilidad es el apartado 2 del artículo 106, que reza:

«Los particulares, en los términos establecidos por la ley, tendrán derecho a ser indemnizados por toda lesión que sufran en cualquiera de sus bienes y derechos, salvo en los casos de fuerza mayor, siempre que la lesión sea consecuencia del funcionamiento de los servicios públicos».

Esta regla, inimaginable hace todavía no muchas décadas, no fue sin embargo nueva en nuestro ordenamiento. En efecto, ya una Ley de 1954 (la de expropiación forzosa, de 16 de diciembre) rompió un principio que, al menos en la interpretación literal de la norma correspondiente, excluía la posibilidad de obtener una indemnización por los daños causados por el Estado, al exigir como condición que el Estado hubiese actuado por mediación de un «agente especial»; esto es, no cuando el daño hubiese sido causado por el funcionario «a quien propiamente corresponda la gestión practicada». Esto decía el hoy desaparecido párrafo quinto del artículo 1.903 del Código civil.

En la Ley de expropiación forzosa de 1954, de una forma ciertamente curiosa desde el punto de vista de la técnica legislativa, se «aprovechó la oportunidad» para insertar un artículo 121 que dispuso:

«Dará también lugar a indemnización con arreglo al mismo procedimiento toda lesión que los particulares sufran en los bienes y derechos a que esta Ley se refiere, siempre que aquélla sea consecuencia del funcionamiento normal o anormal de los servicios públicos, o la adopción de medidas de carácter discrecional no fiscalizables en vía contenciosa, sin perjuicio de las responsabilidades que la Administración pueda exigir de sus funcionarios con tal motivo».

La misma norma se reprodujo, casi textualmente, en el artículo 40 de la que hoy nos parece ya vetusta Ley de régimen jurídico de la Administración del Estado, de 26 de julio de 1957, al decir: 
«Los particulares tendrán derecho a ser indemnizados por el Estado de toda lesión que sufran en cualquiera de sus bienes y derechos, salvo en los casos de fuerza mayor, siempre que aquélla fuese una consecuencia del funcionamiento normal o anormal de los servicios públicos o de la adopción de medidas no fiscalizables en vía contenciosa».

Promulgada la Constitución, la Ley de régimen jurídico de las Administraciones públicas y del procedimiento administrativo común, de 26 de noviembre de 1992, dedica su Título X, artículos 139 a 146, a la responsabilidad de las Administraciones públicas y de sus autoridades y demás personal a su servicio. Importa la reproducción del artículo 139 y del apartado 1 del 141, que dicen:

«Artículo 139. Principios de la responsabilidad

1. Los particulares tendrán derecho a ser indemnizados por las Administraciones Públicas correspondientes, de toda lesión que sufran en cualquiera de sus bienes y derechos, salvo en los casos de fuerza mayor, siempre que la lesión sea consecuencia del funcionamiento normal o anormal de los servicios públicos.

2. En todo caso, el daño alegado habrá de ser efectivo, evaluable económicamente e individualizado con relación a una persona o grupo de personas.

3. Las Administraciones Públicas indemnizarán a los particulares por la aplicación de actos legislativos de naturaleza no expropiatoria de derechos y que éstos no tengan el deber jurídico de soportar, cuando así se establezca en los propios actos legislativos y en los términos que especifiquen dichos actos.

4. La responsabilidad patrimonial del Estado por el funcionamiento de la Administración de Justicia se regirá por la Ley Orgánica del Poder Judicial».

«Artículo 141. Indemnización.

1. Sólo serán indemnizables las lesiones producidas al particular provenientes de daños que éste no tenga el deber jurídico de soportar de acuerdo con la Ley. No serán indemnizables los daños que se deriven de hechos o circunstancias que no se hubiesen podido prever o evitar según el estado de los conocimientos de la ciencia o de la técnica existentes en el momento de producción de aquéllos, todo ello sin perjuicio de las prestaciones asistenciales o económicas que las leyes puedan establecer para estos casos».

Debe advertirse que la redacción originaria del apartado 1 del artículo 141 fue «mitigada», muy razonablemente, en virtud de reforma por Ley de 13 de enero de 1999: se introdujo la causa de exclusión de antijuridicidad -según una determinada interpretación- consistente en el llamado «estado de la ciencia». 
Se observa que el régimen es el de responsabilidad patrimonial de las Administraciones públicas en general (por cierto, tan abundantes en España), no sólo del Estado.

2. Particular interés, y notable discrepancia doctrinal, se ha suscitado en España en relación con la conocida como responsabilidad patrimonial del Estado legislador, también llamada por el hecho de las leyes.

La cuestión se planteó en nuestro país como consecuencia de un gran número de sentencias (cerca del centenar) en las que la Sala de lo Contencioso-administrativo del Tribunal Supremo -empezando por la de 22 de febrero de 2000- estimó la responsabilidad patrimonial del Estado como autor de una Ley luego anulada por el TC. Se trataba de una Ley de 29 de junio de 1990, que estableció la medida tributaria consistente en un «gravamen complementario» sobre máquinas de juegos de azar. Empresarios del sector entablaron abundantes demandas de responsabilidad patrimonial, que, como queda dicho, fueron estimadas. Ocurre que la Ley en cuestión había sido declarada inconstitucional por la sentencia del TC de 31 de octubre de 1996, por infracción del principio constitucional (artículo 9.3) de irretroactividad de las normas restrictivas de derechos individuales. La sentencia del Constitucional no especificó, ni en sus fundamentos jurídicos ni en su fallo, los efectos de tal declaración de inconstitucionalidad y consiguiente nulidad del referido impuesto.

La Sala Tercera del Supremo declaró que la responsabilidad patrimonial de las Administraciones públicas es aplicable a la responsabilidad del Estado legislador, añadiendo que existe una notable tendencia en la doctrina y en el Derecho comparado a admitir que, declarada inconstitucional una Ley, pueda generar un pronunciamiento de reconocimiento de responsabilidad patrimonial cuando se cause privación de derechos y lesión de bienes, derechos o intereses jurídicos protegibles. Se añadía que los actos administrativos de liquidación del impuesto de que se trataba habían sido actos nulos de pleno derecho, calificándose como esencialmente antijurídico el daño producido por dichos actos de recaudación tributaria. Dijo también la Sala Tercera que no era de aplicación el artículo 40.1 de la Ley Orgánica del Tribunal Constitucional, según el cual las sentencias declaratorias de la inconstitucionalidad de Leyes no permitirán revisar procesos fenecidos mediante sentencias con fuerza de cosa juzgada en los que se haya hecho aplicación de las Leyes, disposiciones o actos inconstitucionales. Manifestó así mismo la Sala que la acción de responsabilidad del caso no se computaría desde la fecha de la producción del daño cuya reparación se pretende, sino a partir de la publicación en el Boletín Oficial del Estado de la sentencia correspondiente del Tribunal Constitucional. Incluso más, se declaró por la Sala Tercera que el interesado podría en todo caso pedir la declaración de oficio de la nulidad de pleno derecho del acto administrativo denegatorio de la indemnización, sin sujeción a plazo alguno. Por todo ello, la Sala Tercera acordó la devolución 
a los recurrentes del importe íntegro del impuesto en cuestión, más los intereses legales.

Esta jurisprudencia del Tribunal Supremo ha sido objeto de algunas severas críticas, sobre todo las muy documentadas del Profesor GARCíA DE ENTERRÍA ${ }^{36}$.

\section{H. Leyes de desarrollo de normas constitucionales atinentes al Derecho de daños}

Como he señalado antes, y por otra parte es obvio, la promulgación de la Constitución española ha dado lugar a un elevado número de leyes. Unas, de ajuste a la Carta Magna de disposiciones legales preconstitucionales. Otras, de desarrollo o conversión en legalidad ordinaria de normas o principios de la Ley Fundamental.

En materia de Derecho de daños, el Código civil ha experimentado una ligerísima modificación. Consiste en la supresión, por Ley de 7 de enero de 1991, del antiguo y originario párrafo quinto de dicho precepto, que se refería a la llamada «responsabilidad civil del Estado». Se produjo esa supresión, explicable, porque se había promulgado ya la Ley de régimen jurídico de las Administraciones públicas y del procedimiento administrativo común, de 26 de noviembre de 1992, que dio una nueva fisonomía a la conocida como responsabilidad patrimonial de las Administraciones públicas, según antes hemos visto.

En cuanto a Leyes posteriores a la Constitución en materia de responsabilidad civil, además de la citada de régimen jurídico de las Administraciones públicas pueden mencionarse las siguientes:

- La Ley Orgánica de 5 de mayo de 1982, de protección civil del derecho al honor, a la intimidad personal y familiar y a la propia imagen, modificada parcialmente por Ley Orgánica de 23 de noviembre de 1995. Se trata de un texto legal de desarrollo del artículo 18.1 de la Constitución y que ha dado lugar a una abundantísima jurisprudencia civil. Y también, desde luego, a una muy nutrida jurisprudencia constitucional.

${ }^{36}$ La responsabilidad patrimonial del Estado legislador en el Derecho español, Aranzadi, Cizur Menor, 2005, sobre todo capítulo VI, pp. 223-ss. GARCía DE ENTERRÍA entiende que sólo es posible en España la responsabilidad patrimonial del Estado por actos legislativos cuando éstos desconocen o infringen normas superiores de los ordenamientos comunitarios o internacionales dotados del principio de primacía normativa y, por tanto, con capacidad reactiva o neutralizadora de la norma inferior que puede hacer valer el mismo juez. Es decir, en una situación que coloca a los jueces nacionales, respecto de las Leyes, en una análoga a la que tienen en relación con las normas reglamentarias (pp. 135 y 244). 
- Ley de 19 de julio de 1984, general para la defensa de los consumidores y usuarios, modificada en parte por Ley de 13 de abril de 1998. Como manifiesta su preámbulo, obedeció al designio de hacer verdad el principio (uno de los «principios rectores de la política social y económica» del Capítulo tercero del Título I, artículos 39 a 52) de que «los poderes públicos garantizarán la defensa de los consumidores y usuarios, protegiendo, mediante procedimientos eficaces, la seguridad, la salud y los legítimos intereses económicos de los mismos» (artículo 51.1). Como decía, el preámbulo de la Ley hace expresa alusión a la Constitución, al igual que algunos de sus artículos (entre estos últimos, el 31, sobre arbitraje de consumo, en pro de la tutela judicial efectiva del artículo 24 de la Ley Fundamental).

- La Ley de 21 de abril de 1998, de residuos, invoca el carácter de competencia del Estado de la legislación básica sobre protección del medio ambiente, con fundamento en la Constitución.

- Respondió también a requerimientos constitucionales, según se dice expresamente en algunos lugares de su articulado, la Ley Orgánica de 13 de diciembre de 1999, de protección de datos de carácter personal. La Constitución es citada en sus artículos 7 y 49.

- La Ley de 14 de noviembre de 2002, reguladora de la autonomía de los pacientes y de los derechos de información y documentación clínica, se justifica expresamente sobre la base del derecho a la protección de la salud, calificado como tal (es decir, «derecho», no principio) en el artículo 43.1 de la Constitución.

Otras leyes que establecen reglas de responsabilidad civil y se refieren, con más o menos intensidad, a la Constitución son las siguientes: Ley de 2 de agosto de 1985, de aguas; Ley de 12 de julio de 1988, de auditoría de cuentas; Ley de 28 de julio de 1988, de costas; Ley de 11 de noviembre de 1988, general de la publicidad; Ley de 17 de julio de 1989, de defensa de la competencia; Ley de 15 de octubre de 1990, del deporte; Ley de 10 de enero de 1991, de competencia desleal; Ley de 24 de noviembre de 1992, de puertos del Estado y de la Marina Mercante; Ley de 23 de marzo de 1995, sobre crédito al consumo, luego modificada por Leyes posteriores; Ley de 6 de julio de 1995, reguladora de los viajes combinados; Ley de 15 de enero de 1996, de ordenación del mercado minorista; Ley de 13 de abril de 1998, sobre las condiciones generales de la contratación; Ley de 15 de diciembre de 1998, reguladora de los derechos de aprovechamiento por turno de bienes inmuebles de uso turístico; Ley de 5 de noviembre de 1999, de ordenación de la edificación; Ley de 23 de diciembre de 1999, sobre el régimen jurídico de la tenencia de animales potencialmente peligrosos; Ley de 7 de enero de 2000, de enjuiciamiento civil, sobre todo en materia de legitimación para la defensa de derechos e intereses de consumidores y usuarios; Ley Orgánica de 12 de enero de 2000, reguladora de la responsabilidad penal de los 
menores; Ley de 7 de diciembre de 2001, de marcas; Ley de 1 de julio de 2002, de prevención y control integrados de la contaminación; Ley de 11 de julio de 2002, de servicios de la sociedad de la información y de comercio electrónico; Ley de 7 de julio de 2003, de protección jurídica del diseño industrial; Ley de 7 de julio de 2003, de seguridad aérea; Ley de 9 de julio de 2003, concursal; Ley de 10 de julio de 2003, de garantías en la venta de bienes de consumo; Ley de 17 de noviembre de 2003, del ruido; Ley de 19 de diciembre de 2003, de firma electrónica; Real Decreto Legislativo de 29 de octubre de 2004, texto refundido de la Ley sobre responsabilidad civil y seguro en la circulación de vehículos a motor; Ley de 5 de junio de 2006, ampliando los medios de tutela de los derechos de propiedad intelectual e industrial, y Ley de 7 de julio de 2006, por la que se modifica el texto refundido de la Ley de propiedad intelectual.

De otro lado, debe tenerse presente que la Ley Orgánica del Poder Judicial, de 1 de julio de 1985, en su Título V, artículos 292 a 297, regula la responsabilidad patrimonial del Estado por el funcionamiento de la Administración de Justicia. El capital artículo 292 dispone:

«1. Los daños causados en cualesquiera bienes o derechos por error judicial, así como los que sean consecuencia del funcionamiento anormal de la Administración de Justicia, darán a todos los perjudicados derecho a una indemnización a cargo del Estado, salvo en los casos de fuerza mayor, con arreglo a lo dispuesto en este Título.

2. En todo caso, el daño alegado habrá de ser efectivo, evaluable económicamente e individualizado con relación a una persona o grupo de personas.

3. La mera revocación o anulación de las resoluciones judiciales no presupone por sí sola derecho a indemnización» ${ }^{37}$.

No puede dejarse de señalar, igualmente, que fue posterior a la Constitución la promulgación del vigente Código penal, de 23 de octubre de 1995 , cuyos artículos 109 a 122 regulan la mal llamada responsabilidad civil derivada de delito, materia que, como consecuencia de una verdadera «curiosidad histórica», se viene regulando, a pesar de su carácter civil, en el Código penal.

$\mathrm{El}$ «marco constitucional» se encuentra también en la raíz de otras Leyes que no pertenecen en rigor al terreno de la responsabilidad civil, pero están

${ }^{37}$ Existe, como es lógico, una copiosa jurisprudencia constitucional sobre la materia. Entre las últimas sentencias del Tribunal Constitucional sobre error judicial, procede la cita de la de 8 de mayo de 2006, que otorgó el amparo solicitado por los recurrentes, reconociendo el error de hecho padecido por un órgano judicial. De lo que la Sala dedujo vulneración del derecho constitucional a la tutela judicial efectiva sin indefensión. 
próximas a él. Por ejemplo, la Ley de 8 de octubre de 1999, de solidaridad con las víctimas del terrorismo ${ }^{38}$.

\section{El efecto de principios constitucionales en la jurisprudencia sobre respon- sabilidad civil}

Sería interminable el elenco de preceptos, extremos o aspectos en los que la jurisprudencia civil española, con más o menos intensidad, viene invocando reglas o principios de la Constitución. Por eso, me limito a algunos puntos en los que la presencia de la Constitución en la doctrina de los Tribunales, en concreto del Supremo, ha sido más patente.

\section{A) PRINCIPIO 'PRO DAMNATO' Y 'PEREGRINAJE DE JURISDICCIONES'}

Me refiero ahora a un extremo que, partiendo de una singular sentencia, a la que enseguida aludiré, dio lugar a una doctrina jurisprudencial de enorme importancia práctica. Una doctrina que, formalmente hablando, parecería heterodoxa y de significativa ruptura con criterios anteriores.

En el momento actual, la solución jurisprudencial a la que me refiero carece casi de relevancia, porque, en virtud de reciente reforma de la Ley reguladora de la Jurisdicción contencioso-administrativa, es claro que toda reclamación de responsabilidad patrimonial contra una Administración pública tiene que sustanciarse ante la referida Jurisdicción, con exclusión de cualquier otra. Sin embargo, no era así cuando la doctrina jurisprudencial en cuestión adquirió, salvo contadas excepciones, carta de naturaleza en nuestro Derecho.

El punto de partida es el de que, con la legalidad vigente antes de 1999, las reglas en materia de jurisdicción competente imponían de forma inexcusable, al menos en una interpretación literal, que las demandas de responsabilidad contra la Administración se ventilaran ante la contencioso-administrativa cuando la demandada era únicamente la Administración; esto es, no cuando además se demandaba a un funcionario, caso en el que se admitía pacíficamente la competencia del orden jurisdiccional civil.

Pero hubo un leading case, en terminología de los anglosajones, en el que el criterio se quebró, con manifiesta aplicación del principio pro damnato y con explícito soporte en el derecho a la tutela judicial efectiva del artículo 24 de la Constitución.

Se trató de la sentencia de 5 de julio de $1983^{39}$, cuya doctrina siguieron

${ }^{38}$ He tenido la oportunidad, y el honor, de desarrollar esta materia en el prólogo a un libro del Doctor GiL Botero, de Medellín (en este caso de Colombia). Parece que la obra va a ver la luz pronto, cuando se escriben estas líneas.

${ }^{39}$ Fue comentada por Zorrilla RuIZ y por mí en Anuario de Derecho civil, 1984, octubre-diciembre, pp. 1237-1257 (»Responsabilidad civil de la Administración. Jurisdicción competente y otros extremos»). 
muchas otras posteriores, aunque no faltó alguna que se orientó en una interpretación más literal de las reglas procesales propias del problema.

El esposo de la demandante había fallecido como consecuencia de los disparos efectuados por un funcionario de Policía. Alegaba la actora que el subinspector de Policía había actuado con manifiesta desproporción, al disparar por la espalda al fallecido mientras éste se hallaba de cara a una pared y otro funcionario le colocaba las esposas. Se decía en la demanda que la muerte del detenido era constitutiva de un ilícito civil, del cual respondía subsidiariamente la Administración del Estado, por mandato del artículo 1.903 del Código civil. Y, de hecho, sólo fue demandada esa Administración del Estado; quiere decir que no se demandó a los policías actuantes.

El Abogado del Estado contestó a la demanda sosteniendo en primer lugar que la actuación del policía se había debido a la conducta del propio interfecto, que en el momento en que estaba siendo esposado amagó una agresión contra los agentes de Policía con una navaja que portaba. Se advertía que la demanda se había dirigido sólo contra la Administración del Estado, no contra el agente de Policía. Y terminó suplicando sentencia por la que se declarase la incompetencia de la jurisdicción ordinaria para conocer la pretensión aducida por la actora, por corresponder a la jurisdicción contencioso administrativa; y por la que, subsidiariamente, se desestimase en su integridad la demanda planteada.

El Juzgado de Primera Instancia dictó sentencia por la que, estimando la excepción de incompetencia de jurisdicción propuesta por la parte demandada, declaraba absuelta a ésta, sin entrar a conocer el fondo de la cuestión.

Apelada la sentencia, la Audiencia la confirmó íntegramente.

La Sala Primera del Tribunal Supremo declaró haber lugar al recurso de casación de la demandante, diciendo, en lo que ahora interesa, lo siguiente:

«... con el factor adicional que, notoriamente, resulta del aplazamiento, implicado en la estimación de la cuestión de competencia esgrimida por el representante de la Administración, tesis inaceptable que, además, desde la vertiente de la víctima, ofrecería la, insoportable, perspectiva de causar, día a día, un irreparable perjuicio a siete menores de edad, cuyo derecho a ver cubiertas sus necesidades físicas y espirituales de todo orden, es incuestionable y merecedor de que la dudosa cuestión competencial, bascule del lado de la Jurisdicción civil, matriz de las especializadas, $\mathrm{y}$, de suyo, atractiva, ofreciendo así una solución razonable que, por otra parte y muy principalmente, encuentra inconmovible apoyatura, que importa subrayar con el debido énfasis, en la calificada por conocidísima doctrina como 'vinculación más fuerte' refiriéndose, naturalmente, a la Constitución promulgada el 27 diciembre 1978, a cuyo orden de valores se encuentran, directamente, vinculados, al mismo tiempo que los ciudadanos, las Autoridades y Tribunales de todo orden, los cuales, en su misión de aplicar, incluso las disposiciones de rango legal, han de hacer siempre un juicio de constitucionalidad, negando validez, según el sentir general 
de la doctrina, a toda norma que contradiga el cuadro de valores básicos, constitucionalmente establecidos y dejando de aplicar -virtualidad también negativa- en las concretas controversias que, ante ellos se susciten, tanto las claramente inconstitucionales, como las que, por las especiales circunstancias del caso, manifiestamente restrinjan el derecho a obtener la tutela efectiva de los derechos e intereses legítimos o produzcan, prácticamente, un estado de indefensión contrario al derecho fundamental consagrado por el art. 24 del texto constitucional, tal y como sucedería en este caso en el que, si algo está claro, es que la declaración de incompetencia del Tribunal Civil, a los nueve años largos de ocurrir el luctuoso suceso que sumió en la miseria a la demandante y sus hijos, quedados en situación calificada por el informe de la Alcaldía de Barcelona, ya en 20 febrero 1979 , como de 'francamente deplorable', obviamente significaría embarcarlos en una nueva búsqueda de Juez competente, para entablar un nuevo proceso en el que, a lo largo de todas sus instancias y vicisitudes, tratar de obtener la satisfacción de un legítimo interés indemnizatorio, que tuvo su origen en la lesión de otro derecho constitucionalmente declarado fundamental (art. 15 de la C. E.) después de haberlo perseguido, estérilmente, primero en vía penal -sumario 56/1974 del Juzgado núm. 2 de los de Barcelona- luego en reclamación administrativa - escrito al M. ${ }^{\circ}$ del Interior de 2 febrero 1978- y por último ante la Jurisdicción ordinaria en este proceso presente».

Se advierte, pues, cómo el Tribunal Supremo, al socaire del principio constitucional de tutela judicial efectiva, libró a la demandante -contra lo que parecía ser una interpretación fundada de la legalidad aplicable- de una «nueva búsqueda de juez competente». Es decir, la liberó de lo que la doctrina ha llamado un «peregrinaje de jurisdicciones».

\section{B) DIFUMINACIÓN DE LOS LÍMITES ENTRE RESPONSABILIDAD CONTRACTUAL Y EXTRACONTRACTUAL}

Sabidas son las dificultades conceptuales que entraña la distinción, característica de los sistemas jurídicos inspirados en el Código civil francés, entre responsabilidad contractual y extracontractual. Sabido es también el formidable problema que supone, en presencia de muchos casos concretos, determinar si se está ante una responsabilidad u otra. Y conocido es también que todo no queda ahí, sino que el dilema -y esto es lo importante- lleva consigo consecuencias prácticas de gran calado, una de las cuales es la del diferente plazo de prescripción de ambas acciones (al menos en España). Lo que, en definitiva, se traduce en el riesgo de que una pretensión pueda fracasar si el demandante califica la responsabilidad del demandado de una forma distinta de la en que lo hace el Tribunal que debe resolver, al menos si se interpreta de una forma muy estricta el concepto de causa de pedir y el principio ius novit curia.

Pues bien, en la segunda mitad de la década de los noventa, sobre todo, el Tribunal Supremo acuñó una doctrina que hoy puede calificarse de predo- 
minante. Nos referimos a la teoría llamada «de la unidad de la culpa civil», por cuya virtud el perjudicado por un comportamiento dañoso puede basar su pretensión contra el dañador invocando de forma conjunta o cumulativa la fundamentación jurídica propia de la responsabilidad contractual (artículos 1.101 y concordantes) y de la extracontractual (artículos 1.902 y sus concordantes también).

Son muy abundantes las sentencias de la Sala Primera del Supremo en este sentido, pero a modo de ejemplo cito la de 24 de julio de 1998, que declaró no haber lugar al recurso de casación interpuesto por la demandada, contra la sentencia de la Audiencia que le había condenado a una indemnización por daños. Dice la resolución, en la que se advierten las referencias a la doctrina del Tribunal Constitucional:

«Efectivamente, aunque la jurisprudencia de esta Sala ha proclamado en numerosas sentencias que las normas de la responsabilidad contractual y las de responsabilidad extracontractual fundamentan dos pretensiones distintas (SS. 12 marzo 1934, 24 junio 1969, 2 enero 1978 y 1 abril 1990, entre otras muchas), sin embargo, como opina parte de la moderna doctrina científica, sería un error deducir que si el perjudicado ha fundamentado jurídicamente su demanda de indemnización, ya en normas de responsabilidad extracontractual, ya de responsabilidad contractual, exclusivamente, el juzgador no podrá estimarla o desestimarla, aplicando las normas que regulan la otra responsabilidad, sin incurrir en incongruencia por cambio de la causa de pedir.

Esta postura doctrinal es lógica y se asume totalmente desde el punto de vista del principio iura novit curia perfectamente desarrollada por la corriente doctrina germánica de la freie revisions praxis, que permite al juzgador dar la norma jurídica aplicable al factum alegado y probado, aunque en la pretensión no se alegue la misma, e incluso cuando se alegue otra norma con distinto contenido. Y así lo ha entendido el Tribunal Constitucional en la emblemática Sentencia de 5 mayo 1982, cuando en ella se dice que los Tribunales no tienen ni necesidad ni obligación de ajustarse, en los razonamientos jurídicos que les sirven para motivar sus fallos, a las alegaciones de derecho de las partes, y pueden basar sus decisiones en fundamentos jurídicos distintos, pues a ello les autoriza la regla del aforismo iura novit curia. Siendo asumida dicha tesis por el Auto del Tribunal Constitucional de 16 mayo 1984. Todo ello corroborado por lo dispuesto en la Sentencia de esta Sala de 18 febrero 1997 que afirma: "Sostiene, en efecto, la Sentencia de esta Sala de 1 abril 1994 que debe reconocerse como aplicable el principio inspirador de la jurisprudencia acerca de la llamada 'unidad de la culpa civil' (Sentencias de 24 marzo y 23 de diciembre 1952, entre otras) que en los 'supuestos de concurrencia de acciones de resarcimiento originadas en contrato y a la vez en un acto ilícito extracontractual' señalan como 'doctrina comúnmente admitida que el perjudicado puede optar entre una u otra acción cuando el hecho causante del daño sea al mismo tiempo incumplimiento de una obligación contractual y violación del deber general de no causar daño a otro', junto con los límites estrictos a que se ciñe la 
responsabilidad contractual en casos de coexistencia o conjunción con responsabilidad aquiliana, de manera 'que no es bastante que haya un contrato entre partes para que la responsabilidad contractual opere necesariamente con exclusión de la aquiliana sino que se requiere para que ello suceda la realización de un hecho dentro de la rigurosa órbita de lo pactado y como desarrollo del contenido negocial (Sentencia de 9 marzo 1983, entre otras muchas)', criterios jurisprudenciales que gozan de manifestada continuidad en cuanto a la referida 'unidad conceptual' (Sentencia de 20 diciembre 1991) que admite concurrencia de culpas por los mismos hechos (Sentencia del Tribunal Supremo de 11 febrero 1993)" o "yuxtaposición de las responsabilidades contractuales y extracontractuales que dan lugar a acciones que pueden ejercitarse alternativa o subsidiariamente $u$ optando por una $u$ otra e incluso proporcionando los hechos al juzgador para que éste aplique las normas de concurso de ambas responsabilidades que más se acomoden a ellos, todo en favor de la víctima y para el logro de un resarcimiento del daño lo más completo posible" (Sentencia del Tribunal Supremo de 15 febrero 1993). Y más adelante añade: "proyectado al caso el principio inspirador señalado y los criterios jurisprudenciales enunciados puede decirse que amparada una determinada pretensión procesal en unos hechos constitutivos de la causa petendi en términos tales que admitan, sea por concurso ideal de normas, sea por concurso real, calificación jurídica por culpa, bien contractual, bien extracontractual o ambas conjuntamente salvado -por iguales hechos y sujetos concurrentes-, el carácter único de la indemnización no puede absolverse de la demanda con fundamento en la equivocada o errónea elección de la norma de aplicación aducida sobre la culpa, pues se entiende que tal materia jurídica pertenece al campo del iura novit curia y no cabe eludir por razón de la errónea o incompleta elección de la norma el conocimiento del fondo, de manera que el cambio del punto de vista jurídico en cuestiones de esta naturaleza no supone una mutación del objeto litigioso. $\mathrm{O}$ dicho con otras palabras, no cabe excusar el pronunciamiento de fondo en materia de culpa civil si la petición se concreta en un resarcimiento aunque el fundamento jurídico aplicable a los hechos sea la responsabilidad contractual, en vez de la extracontractual o viceversa"».

Es fácil imaginar el formidable efecto que en la práctica del Derecho en España ha implicado esta doctrina jurisprudencial de la «unidad de la culpa civil».

\section{C) Significado 'Constitucional' De algunas 'INMisiones'}

Las inmisiones (de ruido, humos, olores, vibraciones, polvo, etc. ${ }^{40}$ ) tradicionalmente emplazadas en la doctrina de las relaciones de vecindad,

${ }^{40}$ Hoy se llega a hablar de la inmisión lumínica. Y también está muy de moda la posible inmisión de campos electromagnéticos derivados de tendidos eléctricos de alta tensión o de antenas, materia de la que he escrito últimamente. 
encuentran ya hace varias décadas sede propicia en el ámbito de la responsabilidad extracontractual. En el Código civil español, artículo 1.908, que recoge supuesto de «responsabilidad por el hecho de las cosas», sobre todo de lo que hoy llamaríamos «industria».

En este punto se ha producido recientemente en España una curiosa traducción constitucional del derecho de quien sufre la inmisión, llegándose a hablar, en el caso del ruido, de una violación del derecho a la salud de quien sufre la inmisión e incluso de una violación de su derecho fundamental a la intimidad personal y familiar ${ }^{41}$.

Basta ahora la cita de la sentencia del Tribunal Constitucional de 24 de mayo de 2001. A pesar de ser una sentencia desestimatoria, admite que es posible establecer una relación inmediata entre las inmisiones medioambientales y los derechos fundamentales, que se traduce en que la falta de actuación de la Administración competente (que no evita la contaminación acústica generada por establecimientos de ocio) puede significar la vulneración de los derechos a la integridad física, a la intimidad personal y familiar y a la inviolabilidad del domicilio.

Había habido el precedente del recurso de amparo formulado por la señora López Ostra, que alegó el daño derivado de las inmisiones originadas por los malos olores, el humo y el ruido de una planta depuradora de aguas residuales próxima a su domicilio. $\mathrm{El} \mathrm{TC}$, por providencia de 26 de febrero de 1990, inadmitió la demanda de amparo. Acudió la señora López Ostra al Tribunal Europeo de Derechos Humanos, dictándose por éste la sentencia de 9 de diciembre de 1994 (Caso López Ostra contra Reino de España), en la que se declaró que había habido violación del artículo 8 del Convenio Europeo para la protección de los derechos humanos y de las libertades fundamentales $^{42}$, suscrito en Roma el 4 de noviembre de 1950 y ratificado por España el 26 de setiembre de 1979. Se condenó al Estado español a abonar a la demandante una cantidad en concepto de perjuicios y otra en el de gastos y costas.

${ }^{41} \mathrm{~V}$. en la reciente doctrina española, FERNÁNDEZ URZAINQUI, La tutela civil frente al ruido, Civitas, Madrid, 2003. También, EgEA FeRnÁndEZ, «Relevancia constitucional de las inmisiones por ruido ambiental procedente de una zona de ocio nocturno. Recepción de la jurisprudencia del Tribunal Europeo de Derechos Humanos (Comentario a la STS 119/2001, de 24 de mayo)», en Derecho privado y Constitución, 15, 2001, pp. 69-ss.

${ }^{42}$ Dice: «1. Toda persona tiene derecho al respeto de su vida privada y familiar, de su domicilio y de su correspondencia. 2. No podrá haber injerencia de la autoridad pública en el ejercicio de este derecho, sino en tanto en cuanto esta injerencia esté prevista por la Ley y constituya una medida que, en una sociedad democrática, sea necesaria para la seguridad nacional, la seguridad pública, el bienestar económico del país, la defensa del orden y la prevención del delito, la protección de la salud o de la moral, o la protección de los derechos y las libertades de los demás». 
Entre otras cosas, en aquella sentencia dijo el Tribunal Europeo: «Sin embargo, ni que decir tiene que los atentados graves al medio ambiente pueden afectar al bienestar de una persona y privarla del disfrute de su domicilio, perjudicando su vida privada y familiar, sin, por ello, poner en grave peligro la salud de la interesada.

Que se aborde la cuestión bajo el ángulo de una obligación positiva del Estado -adoptar medidas razonables y adecuadas para proteger los derechos del individuo en virtud del apartado 1 del artículo 8-como desea la demandante, o bajo el de "una injerencia de una autoridad pública”, según los términos del apartado 2, los principios aplicables son muy semejantes. En ambos casos hay que tener en cuenta el justo equilibrio entre los intereses concurrentes del individuo y de la sociedad en su conjunto, gozando el Estado en cualquiera de las hipótesis de un cierto margen de apreciación. Además, incluso para las obligaciones positivas que resultan del apartado 1, los objetivos enumerados en el apartado 2 pueden jugar un cierto papel en la búsqueda del equilibrio deseado (ver, en concreto, las Sentencias Rees contra Reino Unido de 17 de octubre de 1986, serie A, n. ${ }^{\circ} 106$, pág. 15, apartado 37, y Powe y Rayner contra Reino Unido de 21 de febrero de 1990, serie A, n. ${ }^{\circ}$ 172, pág. 18 apartado 41)».

Por ello, concluyó: «Teniendo en cuenta lo que antecede -y a pesar del margen de apreciación reconocido al Estado demandado-, el Tribunal estima que éste no ha sabido mantener un justo equilibrio entre el interés del bienestar económico de la ciudad de Lorca -el de disponer de una planta depuradora- y el disfrute efectivo por la demandante del derecho al respeto de su domicilio y de su vida privada y familiar».

Inspirado en esta sentencia del Tribunal Europeo, el Constitucional español, en su sentencia de 3 de diciembre de 1996, aunque desestimó el recurso del caso, dijo: "La importancia del derecho al medio ambiente ha sido puesta de relieve también por el Tribunal Europeo de Derechos Humanos que ha declarado que, en determinados casos de especial gravedad, los daños ambientales pueden llegar a vulnerar el derecho de una persona a su vida personal y familiar, declarado por el art. 8 del Convenio de Roma (Sentencias del TEDH Powell y Rainer c. Reino Unido, 21 de febrero de 1990, y López Ostra c. España, 9 de diciembre de 1994)».

En la sentencia que he citado al principio, de 24 de mayo de 2001, el Tribunal Constitucional manifestó: «Partiendo de la doctrina aquí expuesta en apretada síntesis, debemos señalar que estos derechos han adquirido también una dimensión positiva en relación con el libre desarrollo de la personalidad, orientada a la plena efectividad de estos derechos fundamentales. En efecto, habida cuenta de que nuestro texto constitucional no consagra derechos meramente teóricos o ilusorios, sino reales y efectivos (STC 12/1994, de 17 de enero, F. 6), se hace imprescindible asegurar su protección no sólo frente a las injerencias ya mencionadas, sino también frente a los riesgos que puedan surgir en una sociedad tecnológicamente avanzada. 
A esta nueva realidad ha sido sensible la jurisprudencia del Tribunal Europeo de Derechos Humanos, como se refleja en las Sentencias de 21 de febrero de 1990, caso Powell y Rayner contra Reino Unido; de 9 de diciembre de 1994, caso López Ostra contra Reino de España, y de 19 de febrero de 1998, caso Guerra y otros contra Italia».

\section{D) EL 'DERECHO A LA SALUD' Y LA RESPONSABILIDAD CIVIL}

El artículo 43 de la CE declara en su apartado 1 que «se reconoce el derecho a la protección de la salud». También se menciona la salud en el artículo 51.1, citándose, entre otras garantías de los consumidores, la de su salud.

Pues bien, desde los años ochenta son muchas las sentencias de la Sala Primera del Tribunal Supremo en las que se argumenta (casi siempre en casos de condena) sobre el primero de los dos preceptos constitucionales que he citado. Es frecuente que la Sala invoque dicha norma como de directa aplicación, a pesar de que la protección de la salud se inserta en nuestra Ley Fundamental como uno de los «principios rectores de la política social y económica». A modo de ejemplos, traigo a colación pasajes de algunas sentencias en el sentido apuntado.

Sentencia de 20 de marzo de 1997: «El informe pericial no descarta de modo categórico que la precipitada alta hospitalaria no influyera en la evolución desfavorable del enfermo, pues rotundamente la reputa inoportuna y no aconsejable. No ha de atenderse a la intensidad de la negligencia, basta que concurra y represente falta de diligencia conveniente, cuando se trata de cuestión tan primordial como es la procura, protección y defensa de la salud de las personas, que el artículo 43 de la Constitución reconoce como un derecho, elevado a la condición de básico en el artículo 2.1, a) de la Ley para la Defensa de los Consumidores y Usuarios de 19 julio 1984».

De 7 de abril de 1997: «La negligencia la ocasiona, en este caso, el no haber agotado la ciencia médica en tiempo oportuno y con posibilidades muy próximas de alcanzar resultados serios favorables, así como por la falta de empleo de los medios de curación al alcance, como los más aconsejables y necesarios, y que no revestían nota de ejecución imposible o insalvable, para la procura de la mejor salud del recurrido, pues la importancia de este derecho humano primordial -que la Constitución en su artículo 43 proclama como derecho ciudadano- no puede supeditarse a una deficiente organización burocrática hospitalaria o a meros formulismos, desgraciadamente muy usuales en los ámbitos sanitarios, para eludir los deberes de prestar cuidado eficaz a los pacientes, sin condicionamientos, disculpas ni aplazamientos más o menos convencionales o acomodados a otros intereses ajenos a los que impone la completa asistencia a los enfermos, que confían en el médico y le entregan el don tan preciado como es el cuidado de su salud». 
De 4 de febrero de 1998: «Ahora bien, sentado cuanto antecede y establecida por las razones expuestas, la no responsabilidad de la doctora $O$., debemos ahora analizar, desde un punto de vista más amplio, la posible responsabilidad del INSALUD, como tal y como sustento de la administración sanitaria a realizar a la generalidad de los ciudadanos, dentro del campo de la Seguridad Social. En cuanto a ella el art. 43 de nuestra Constitución recoge en su apartado 1. "el derecho a la protección de la salud", como tal derecho constitucional, y en su apartado 2. ${ }^{\circ}$ establece que: "Compete a los poderes públicos organizar y tutelar la salud pública a través de medidas preventivas y de las prestaciones y servicios necesarios" ". Más adelante, la sentencia insiste: "Así pues, para concluir, entendemos que se dan todos los requisitos necesarios, para que funcione la responsabilidad directa de la Administración, a través del codemandado INSALUD, al no haber proporcionado, como debía, a la actora, los medios necesarios e idóneos en orden a la resolución conveniente de su embarazo, incumpliendo con ello el deber de prestar adecuadamente a aquélla el derecho a una asistencia sanitaria adecuada, encuadrable y protegida por el art. 43.2. ${ }^{a} \mathrm{CE}$; es por ello, que conforme a toda la doctrina expuesta en los fundamentos cuarto, quinto y sexto de la presente, dicha responsabilidad debe traducirse en la correspondiente indemnización de los daños y perjuicios ciertos causados, al amparo de lo dispuesto en los arts. 1902, 1903.1 ${ }^{\circ}$ y $4^{\circ}$ del CC y 106.2 de la propia $C E »$.

De 19 de junio de 1998: «En cuanto a la responsabilidad objetiva de los organismos públicos, la Audiencia la fundamenta -se dice textualmente en el mismo cuarto considerando-del siguiente modo: "Así se deriva, por una parte, del artículo 139 de la LRJ-PAC, y de, otra, del artículo 28 de la LGDCU, normas concurrentes y no excluyentes en estos casos de responsabilidad cuando es la Administración sanitaria la demandada por quien se considera perjudicado por las presentaciones realizadas por aquélla, superando totalmente el sentido culpabilístico del artículo 1902 del CC, preceptos todos ellos que han de ser interpretados conforme a los artículos 41, 43 y 106.2 de la Constitución”.

Estas argumentaciones obviamente tratan en última instancia de fundamentar el fallo condenatorio de los organismos públicos demandados junto a los médicos en la vía civil, pero son totalmente inaceptables porque los artículos 1902 y 1903 CC son partes de un sistema de responsabilidad civil asentado sobre la culpa, nada tiene que ver con el fundamento de los servicios públicos a quienes se imputa el daño. La responsabilidad que de ello nace se regula por las disposiciones administrativas al efecto, que se fundan en el principio de la responsabilidad objetiva de la Administración. Tampoco tiene nada que ver el artículo 28 de la Ley General de los Consumidores y Usuarios de 19 julio 1984 con los artículos de la Constitución citados con el fin de establecer una responsabilidad objetiva, que ya el propio precepto consigna, ni sirve para que los preceptos civiles se interpreten superando el 
principio de la culpa, ni su aplicación desplaza la normativa de la responsabilidad de la Administración por el funcionamiento de los servicios sanitarios. Así las cosas, la razón de la condena a los organismos públicos demandados radica en el daño producido por el funcionamiento de los servicios sanitarios, lo que hubiera debido llevar a la Audiencia a la apreciación de oficio de la competencia de la jurisdicción contencioso-administrativa, no a pronunciar una condena en la vía civil basándose en preceptos de esta naturaleza no aplicables a los hechos que son presupuestos de aquella condena.

Por todo ello el motivo se estima».

Y sentencia de 5 de octubre de 1999, que dijo: «De lo expuesto en el fundamento anterior, se desprende claramente la estimación de la demanda de responsabilidad civil, con base constitucional (artículos 43 y 51 de la Constitución Española), fundamento en el Código Civil (artículo 1902) y apoyo en legislación especial (artículo 28 de la Ley de Consumidores y Usuarios): se ha acreditado el nexo causal entre la actuación -fabricación de producto farmacéutico- de la sociedad demandada y el daño personal y moral que sufre el demandante, siendo intrascendente jurídicamente el elemento de la culpabilidad en esta responsabilidad objetiva».

Por otra parte, son muchas las sentencias del Tribunal Constitucional en las que éste desarrolla el significado del artículo 43 de la Constitución, en relación con lo que solemos conocer como responsabilidad médica, tanto la reclamada a profesionales o a centros sanitarios privados, como a Administraciones sanitarias. Destacan en número las que versan sobre el gran problema jurídico que conocemos como consentimiento informado. El TC ha llegado a hablar del derecho humano a la autodeterminación (la del paciente), en casos de información médica inexistente o insuficiente ${ }^{43}$. Con carácter general, y a modo de simples ejemplos, cito las sentencias de 30 de noviembre de 2000 (protección de datos en la asistencia sanitaria), 29 de junio y 16 de octubre de 2000 (valoración de daños corporales), 26 de octubre de 1996 (relación con libertad religiosa), 2 de octubre de 1996 (negativa a someterse a pruebas biológicas), 14 de julio de 1994 (esterilización de incapaces), 11 de abril de 1994 (imprudencia del médico), 27 de junio de 1990 (huelga de hambre) y 15 de febrero de 1989 (reconocimiento médico forzoso).

${ }^{43}$ Puede encontrarse una exhaustiva recopilación de jurisprudencia, que incluye la del Tribunal Europeo de Derecho Humanos, del Tribunal de Justicia de las Comunidades Europeas y de los Tribunales españoles, en todos los órdenes jurisdiccionales, en la obra colectiva, en la que tuve el honor de participar, Derecho médico. Tratado de Derecho sanitario, Colex, Madrid, 2001, tres volúmenes. La jurisprudencia se encuentra en la segunda parte del I y en todo el II. En la parte doctrinal, volumen I, pp. 1003-ss., ZoRRILLA RUIZ es autor del trabajo «¿Principio constitucional o derecho a la protección de la salud?». 